\title{
Africa's clientelist budget policies revisited: public expenditure and employment in Kenya, Tanzania and Uganda, 1960-2010
}

\begin{abstract}
By REBECCA SIMSON ${ }^{2}$
What can we learn about policy prioritization in Africa by examining long-run trends in public expenditure and employment? Many have contended that the continent's postcolonial leaders pursued economically unproductive budget policies that prioritized the growth of their patronage networks over socially beneficial spending, resulting in bloated payrolls, persistent deficits and a large rent-seeking public service. Using a purpose-built dataset of annual public expenditure and employment series for Kenya, Tanzania and Uganda from 1960-2010 against which to test these assumption, this article questions whether there was anything exceptional about the growth or composition of East Africa's post-independence expenditure. All three states grew and contracted in roughly the same periods as in other regions of the world, although their contraction after 1980 was particularly marked. Industrial policy and capital investments influenced budget priorities in the early independence era, while military expenditure and debt service payments escalated in the late 1970s. The government wage bill, meanwhile, fell as a proportion of total spending over the same period. To finance employment growth whilst the wage bill contracted, governments allowed real wages to plummet in the 1970s-90s. In light of these external constraints and legacies, this article questions whether a budget unencumbered by patronage would have looked so very different.
\end{abstract}

One of Africa's many economic predicaments is supposedly a political settlement that favours public spending on patronage at the expense of growth-enhancing public investments. Many have linked the prevalence of patronage politics to the continent's ethnic heterogeneity. Evidence from across the world has shown that social polarization increases competitive rent-seeking. ${ }^{3}$ Applying these insights to the African context, scholars have argued that the continent's unusually high degree of ethnic polarization has prevented leaders from appealing to national solidarity to gain support for developmental policies. They therefore rely on pork barrel politics, using public funds to strike uneasy bargains that shore up the political support of influential individuals or groups.

These 'neopatrimonial' tendencies in Africa have long been of academic interest. Theory holds that modern administrative and governance institutions function according to a patrimonial logic rather than a legal-rational one. ${ }^{4}$ Under the veneer of a modern state structure, government resources are treated as the private property of the political patrons that control them, and are used to buy the loyalty of supporters rather than deliver broad-based public goods and services. Vertical ethnic and regional ties

\footnotetext{
${ }^{1}$ I would like to thank Leigh Gardner, Tirthankar Roy, Chris Minns, Peter Cirenza, Denis Cogneau, Elliott Green, Thandika Mkandawire, Yannick Dupraz, Ewout Frankema and Kleoniki Alexopoulou for their valuable suggestions or comments on earlier drafts of this paper. I would also like to thank participants of the New Frontiers in African Economic History Workshop, London School of Economics (25 October 2014) and RHI seminar at Wageningen University (14 March 2017). I am also grateful for the helpful advice of the journal editor and four anonymous reviewers of this article.

${ }^{2}$ Author Affiliation: Department of Economic History, London School of Economics

${ }^{3}$ Alesina, Baqir, and Easterly, 'Public goods and ethnic divisions'.

${ }^{4}$ Clapham, Third World Politics, p.48.
} 
that bind the village to the centre trump horizontal class interests, resulting in policy-making that focuses on consumption rather than the public goods. ${ }^{5}$

Econometric studies have sought to identify the political and economic consequences of these patronage structures. Easterly and Levine have argued that ethnic patronage in Africa crowds out public goods provision and worsens economic policymaking. They find a relationship between ethnic polarization and low schooling levels, persistent fiscal deficits and low infrastructural penetration. Such 'socially suboptimal policies' are in turn thought to have retarded economic growth. ${ }^{6}$ Englebert has traced continuities across pre-colonial, colonial and post-colonial governance structures, and similarly concluded that Africa's 'neo-patrimonial policies' are redistributive rather than growth-enhancing, favouring job creation over investment. ${ }^{7}$ Several other studies have likewise argued that political pressures to create public sector jobs were a major drain on African state resources in the first decades of independence and a consequent drag on economic growth. ${ }^{8}$

These patronage pressures are also expected to make fiscal adjustments more difficult. Alesina and Drazen argue that the tendency to delay necessary stabilization reforms, to the detriment of the longerterm health of the economy, is higher in politically polarized societies, where conflict over how to distribute the burden of adjustment more frequently leads to stalemate. ${ }^{9}$

Others have theorised about the role of employment creation specifically, focusing on the unique features of public sector jobs. Acemoglu and Robinson view public sector jobs as the main instrument of patronage politics because '[p]ublic goods cannot be targeted to one's friends and they cannot be withheld from one's foes. Private goods, like jobs, are much more politically attractive. ${ }^{10}$ Robinson and Verdier argued that public sector jobs are a particularly attractive form of patronage because they allow patrons to overcome a time-inconsistency problem. ${ }^{11}$ Because jobs can be withdrawn if clients renege, they ensure continued cooperation. This literature views patronage in Africa as personalised and discretionary. Jobs are given or taken away from individual voters or local leaders and brokers in return for their political support or that of their followers.

Scholars have also found fault with public sector wage setting in Africa, although the diagnoses have changed over time. In the first decades of independence it was often argued that a colonial high wage legacy went hand in hand with pressure to expand the public service, as workers queued in the hopes of securing a lucrative public sector job. This was thought to have created a politically influential urban wage working class that commanded wages well above the reservation price, to the detriment of a highly taxed agricultural sector. ${ }^{12}$ Among the skilled labour force moreover, the removal of racial salary scales in the 1950s, which brought Africans in senior positions up to the salary levels of their colonial predecessors, meant that independent governments were saddled with a senior civil service with salaries set to labour market conditions in the former colonial metropolises. Many expected that this would empower a rent-seeking, public sector class that protected its own interests and restricted the entry into senior posts to members of their own communities. ${ }^{13}$

\footnotetext{
${ }^{5}$ Chabal and Daloz, 'Africa works'.

${ }^{6}$ Easterly and Levine, 'Africa's growth tragedy', p.1214.

${ }^{7}$ Englebert, 'Pre-colonial institutions'.

${ }^{8}$ World Bank, 'Accelerated development', pp. 40-42; Gelb et al. 'Public sector employment'; Bigsten and Moene, 'Growth and rent dissipation', p.185.

${ }^{9}$ Alesina and Drazen, 'Why are stabilizations delayed?'

${ }^{10}$ Acemoglu and Robinson, 'Why is Africa poor?', p.42.

${ }^{11}$ Robinson and Verdier, 'The political economy of clientelism,' p.264.

${ }^{12}$ Arrighi and Saul, 'Socialism and economic development'; Bates, Markets and states.

${ }^{13}$ Bennell, 'The colonial legacy', p. 127.
} 
How strong is the evidence that African governments made these types of sub-optimal policy choices? Was patronage and clientelism mediated through budget policy, and particularly through public employment? Implicit in the patronage literature is the assumption that a less patronage-afflicted polity would have made better allocative choices, which would in turn have spurred growth. This study systematically examines this charge against the expenditure and employment trends in Kenya, Tanzania and Uganda. Using data collected from over a hundred national statistical publications, IMF and World Bank reports, this article assembles a new dataset on public expenditure, employment and wages in the three focus countries, covering the period 1960-2010 and containing close to 10,000 observations. Many past historical studies of public finance in Africa have relied heavily on colonial statistical publications, and thus end their period of study in the early 1960s when colonial statistical collection ceased. ${ }^{14}$ This dataset thus sheds light on a hitherto understudied period in African economic history.

This evidence base challenges several common propositions about postcolonial budget policy: that public spending and public employment grew excessively after independence; that wage spending and other consumption crowded out investment spending; that public sector employment was protected from cuts, or that politically salient regions or groups were so; and lastly, that public sector salaries were protected. It concludes that there is little evidence that expenditure policy disproportionately targeted short-term consumptive objectives over developmental ones, or that structural adjustments were delayed indefinitely. In all three cases the general health of the economy coupled with changing global ideas about the role of the state have left a clearer imprint on government finances than the political break at independence. In aggregate, public spending and employment grew strongly in the 1960s and 1970s then plateaued or contracted in the 1980s as growth slowed and fiscal imbalances worsened. The growing fiscal space in the early independence period was used to promote industrial policy, fund wars and finance debt service successively, while the wage bill acted as a residual. Within the wage budget moreover, employment growth favoured frontline service provision such as primary education, whilst the monetary advantages of a public sector career declined over time as earnings eroded.

These broader expenditure, employment and earnings patterns are by no means incompatible with high levels of corruption or wastage and shed limited light on elite bargains or capture. However, a birdseye view of formal expenditure policy offers a useful perspective on central government policy intent and constraints. Without this broader context, it is hard to debate the counterfactual that motivate the studies discussed above: would a different prioritization of expenditure have set these countries on a different economic path? This article argues that the room for policy manoeuvre shrunk dramatically in the late 1970s and many of the high-level allocative shifts that followed were in fact broadly in line with the advice offered by international organisations. While there were doubtless spending inefficiencies, leakages and costly delays to reform, it is questionable whether their elimination would have been enough to sustain the investment levels of the 1960s, let alone re-orient these economies.

This evidence complements earlier studies that have placed greater emphasis on exogenous shocks, unfavourable external economic conditions and mismanaged industrial policies than political economy failures. ${ }^{15}$ It also complements the findings from several cross-sectional studies, which concluded that African countries had on average smaller civil services and wage bills than other developing regions of the world in the 1980s and 1990s, and threw doubt on the importance of employment as a key mediator

\footnotetext{
${ }^{14}$ For instance: Frankema, 'Colonial taxation'; Gardner, Taxing colonial Africa; Cogneau, Dupraz, and MespleSomps, 'African states'.

${ }^{15}$ For a discussion of external versus domestic causes of the crisis: Cooper, Africa since 1940; Collier and Gunning, 'Why has Africa'; Adedeji, 'Comparative strategies', p.407.
} 
of economic outcomes. ${ }^{16}$ It also reinforces Mkandwire's critique of neopatrimonialism, that as a theoretical framework it holds little predictive value. ${ }^{17}$ Lastly, it builds on a sizable policy literature on Africa's dramatic public sector wage declines over the 1970s through 1990s. ${ }^{18}$ Unlike much of this earlier work, however, this paper uses long-run time series data for a small set of case studies rather than a large sample cross-sectional study. This allows greater insights into whether, how and why newly independent governments sought to alter the composition of spending and respond to shocks.

The three case study countries, Kenya, Tanzania ${ }^{19}$ and Uganda, exhibit many of the features associated with patronage. All three are ethnically fragmented and their governance systems are weak, scoring poorly on international measures of governance quality. ${ }^{20}$ They gained independence in the main wave in the 1960s and their economies performed disappointingly from the mid/late 1970s until the 1990s as their rulers turned increasingly authoritarian. All three undertook structural adjustment reforms in the 1980 s or 1990s and returned to multiparty rule in the 1990s or 2000s. The subregion's economic growth recovered in the 2000s.

These three cases also present some important differences. While Kenya and Uganda's political fault lines are shaped by ethnic cleavages, Tanzania's leaders have been more successful in crafting a national identity that downplays ethnic difference, and Tanzania is therefore thought to be less patronageafflicted. Furthermore, Kenya and Tanzania are often contrasted to highlight the differences between the former's capitalist, and the latter's socialist, political orientations. Lastly, while Kenya and Tanzania remained comparatively peaceful, Uganda experienced decades of conflict following Idi Amin's coup in 1971, with inevitable budgetary consequences.

For each country, the author has built data series on public revenue, expenditure, employment and average wages from the late colonial period until the present. The full dataset is provided in an online appendix, along with a discussion of the sources and the assumptions underlying the key series. The first section of the paper examines the rate of revenue and expenditure growth in aggregate terms, to evaluate if and how African state growth diverged from international trends. The second section turns to the composition of public spending to establish what categories of spending grew in different time periods. The fourth section examines internal wage bill dynamics, and how the level and composition of public employment changed in response to shocks. The fifth section examines public sector wages, and what they tell us about the relative bargaining power of public servants. The last section concludes.

Any evaluation of the pace of state growth in Kenya, Tanzania and Uganda should be set against a backdrop of global change to the size and reach of the state over the course of the past century. In the aftermath of WWII, governments around the world came to take on a far greater range of services and functions than ever before, from the establishment of social safety nets to universal provision of education and healthcare. ${ }^{21}$ Growing state intervention in the productive sectors, through the creation of public corporations and nationalisation of industry, also brought an unprecedented share of industrial employment and investment under state control. This growth of the state was underpinned by the

\footnotetext{
${ }^{16}$ Goldsmith, 'Sizing up the african state'; Goldsmith, 'Africa's overgrown state'; Rodrik, 'What drives public employment'; Schiavo-Campo, de Tommaso, and Mukherjee, 'Government employment and pay'.

${ }^{17}$ Mkandawire, 'Neopatrimonialism', p.564.

18 Jamal and Weeks, 'Africa misunderstood'; Lindauer and Nunberg, Rehabilitating government; Leinert and Modi, 'Civil service reform'.

${ }^{19}$ Mainland Tanzania only. Zanzibar is not included in this analysis.

${ }^{20}$ Worldwide Governance Indicators, www.govindicators.org (accessed on 4 Dec. 2017).

${ }^{21}$ Lindert, Growing public; Tanzi and Schuknecht, Public spending.
} 
Keynesian idea that discretionary fiscal policy could be used to manage aggregate demand and maintain full employment. ${ }^{22}$

According to a global IMF dataset, albeit very sparse on African observations, ${ }^{23}$ expenditure grew substantially across all regions of the world. In Western Europe ${ }^{24}$ public expenditure grew from an average of 11 per cent of GDP in 1890 to 47 per cent in 2000, a more than four-fold increase. In the USA and Canada public expenditure grew from 4 per cent to 38 per cent of GDP over the same period, in India from 7 per cent to 27 per cent, and for a sample of five Latin American countries from 7 per cent in 1905 to 24 per cent in $2000 .{ }^{25}$ Unlike in the 19th and early 20th century, when governments sought to maintain balanced budgets, many countries ran persistent deficits in the post-WWII era. In Europe, Latin America and Asia the primary balance was on average negative during the postwar golden age. ${ }^{26}$

Public expenditures grew rapidly until around 1980, after which state growth slowed or plateaued in most parts of the world, in tandem with the slowdown in economic growth, increased indebtedness and growing deficits. Latin America experienced a decline in spending the 1980s followed by a recovery in the late 1990s. Budget balances, on average, improved during this period of state consolidation.

Although there are fewer comparative studies on public employment growth, the available data suggests a similar trajectory. A study using a sample of six western countries found that government employment roughly doubled as a share of the labour force between 1951 and $1981 .{ }^{27}$ In tandem came the growth of the state-owned enterprise sector, which by the late 1970s employed around 8-15 per cent of the labour force and accounted for over 10-15 per cent of GDP in sample of seven OECD countries. ${ }^{28}$ Since the 1980s however, the level of government employment has stagnated or fallen in many parts of the world, ${ }^{29}$ while employment in public corporations fell as enterprises were privatized.

How do budget trends in Kenya, Tanzania and Uganda compare to this global trajectory? In Figure 1 general government revenue (before grants) and expenditure (including net lending) are plotted as percentages of GDP. ${ }^{30}$ Because of the challenges of estimating historical GDP series in Africa, the figure also presents an alternative series, which presents expenditure trends in constant per capita terms, deflated by the consumer price index. This has the added advantage of incorporating the effect of price changes for the goods traded in East Africa, rather than those produced domestically only. Given the big terms to trade swings over the 1970s and 1980s, this provides a useful view of the government's ability to sustain its level of goods and service provision.

Figure 1 shows that the Kenyan, Tanzanian and Ugandan revenue and expenditure trajectories roughly match the global inflection points, with strong state expansion from the late 1940s through the 1970s and a stagnation or decline thereafter. Independence did not mark a break with the past. The expansion of the African state started well before decolonization and lasted until after the global shocks of the

\footnotetext{
22 Webber and Wildavsky, A history of taxation.

${ }^{23}$ Public finances in modern history database: Binder et al., 'A modern history of fiscal prudence'.

${ }^{24}$ Unweighted average for 14 countries with available long-run data: Austria, Belgium, Denmark, Finland, France, Germany, Greece, Italy, Netherlands, Norway, Portugal, Spain, Sweden and the United Kingdom.

${ }^{25}$ Argentina, Chile, Colombia, Mexico and Peru.

${ }^{26}$ Using data on deficits from: Binder et al., 'A modern history of fiscal prudence'.

${ }^{27}$ Rose, Public employment, p. 11.

${ }^{28}$ Countries with parastatal sectors above $10 \%$ of GDP: France, Austria, Italy, Sweden, UK, Australia, West Germany, see: Hannah, 'A failed experiment', p. 85.

${ }^{29}$ Schiavo-Campo, de Tommaso, and Mukherjee, 'Government employment and pay', Table 3.

${ }^{30}$ The sources and assumptions made in building these time series are discussed in appendix S2.
} 
1970s. ${ }^{31}$ The region saw a marked rise in revenue and expenditure in the immediate postwar era, buoyed by strong demand for commodities during the postwar reconstruction and the Korean War. Revenue slumped briefly in the late 1950s after the end of the Korean War, then resumed in the early 1960s and grew strongly until the early 1980s in Kenya and Tanzania, while in Uganda growth tapered off earlier in the 1970s. This was followed by Africa's economic stagnation, when GDP per capita remained flat or regressed and the level of state expenditure fell. Here the contrast with other regions of the world is more marked. While many OECD and Asian countries saw public expenditure levels plateau in the 1980s, these East African cases, like some Latin American countries, experienced declines in revenue and expenditure relative to GDP and only a partial recovery in expenditure in the 2000s.

\section{[FIGURE 1]}

Yet spending expressed as a share of GDP doesn't fully account for the severity of these expenditure decline. In all three cases, deflating public expenditure by consumer prices rather than expressing it as a share of GDP shows a more marked rise and decline (Figure 1, column 2). Real per capita government spending halved in Kenya and Tanzania over the 1980s and 1990s and fell by a factor of six in Uganda (1970s), partly as a result of the rising cost of imports brought about by worsening terms of trade and currency depreciations. Per capita spending fell back to the levels of the early 1950s, or in the Ugandan case the 1940s. Government spending was therefore hit by a double shock in the 1980s-1990s: expenditure to GDP was reined in at the same time as input costs increased.

Although state growth was not exceptionally fast, East African post-independence deficits were high by international standards, as spending outpaced revenue growth. Budget deficits expanded significantly in the 1970s and 1980s, peaking at almost 7 per cent of GDP in Kenya (1980), 11 per cent in Tanzania (1980) and 11 per cent in Uganda (1973). But these deficits were in large part a consequence of the dual budgeting practices of the 1960s and 1970s rather than uncontrolled consumption spending. The dotted lines in Figure 1 trace the growth in recurrent spending. During the period of strong expenditure growth (1960 - late-1970s, or early 1970s in Uganda), all three countries maintained their recurrent spending below revenue and allowed it to grow in line with revenue growth. This practice was in keeping with the budgeting orthodoxy of the times: recurrent costs were to be kept below recurrent revenue, while capital projects with a projected rate of return above the interest rate could be debtfinanced. ${ }^{32}$ This approach had theoretical backing in the economic literature of the era, which stressed the economic catch-up potential of developing countries by importing capital and technology. ${ }^{33}$

These trends in revenue and expenditure also reveal important country variation. Kenya's economy held up better than its neighbours through the shocks of the 1970s and 80s. The revenue to GDP ratio increased considerably between the late 1950s and early 1980s, then plateaued and fell first in the 1990s with the introduction of structural reforms. Tanzania's spending trend is punctured by the war with Uganda in 1978-9, which caused a sharp increase in expenditure followed by a consolidation in the 1980s.

Uganda stands out as the most extreme case. Revenue as a share of GDP peaked earlier in 1966, with the start of Uganda's postcolonial political upheavals. The country experienced a dramatic fiscal collapse in the mid-1970s, following Idi Amin's 1971 coup and the 1972 expulsion of the Indian community. Revenue fell from 17 per cent to 2 per cent, and expenditure from 23 per cent to 6 per cent. In many years receipts covered less than half of all spending. The official figures probably overstate the

\footnotetext{
${ }^{31}$ As also argued by: Cooper, Africa since 1940.

${ }^{32}$ Uganda, 'Background to the budget 1966/67', p. 43; Government of Tanganyika, 'Development plan for Tanganyika, 1961/62 - 1963/64', pp. 9-12.

${ }^{33}$ Chenery and Strout, 'Foreign assistance'.
} 
true decline in public spending, as record keeping also deteriorated and off-budgetary transactions likely increased. Nonetheless, as an account of official outlays only, this figure is indicative of Uganda's state implosion. After Yoweri Museveni came to power in 1986 the country experienced a rapid recovery and revenue and expenditure returned to their pre-crisis levels.

III.

Turning to a compositional analysis of public expenditure shows little evidence of wages or other consumption spending crowding out the development budget. Figure 2 presents a modified economic classification of general government expenditure to examine how the composition of spending changed over time. In contrast to a normal economic classification, defence (a functional category) is included as an independent spending category in these charts. Note that the Ugandan estimates from the late 1970s and early 1980s should be treated with caution, but the wage bill was, if anything, the most reliable of the public expenditure estimates according to the IMF. ${ }^{34}$

\section{[FIGURE 2]}

This analysis shows that it was indeed the development budget which consumed most of the incremental rise in government expenditure in the first decade of independence. In Kenya and Tanzania the development budget rose from roughly 15 per cent of expenditure at independence to 30 per cent by 1971, while it peaked at 26 per cent in Uganda in 1969. An important objective of Africa's first postcolonial leaders was the development of an industrial base. ${ }^{35}$ Concerned that an undiversified primary commodity-based economy would perpetuate economic dependence, many African governments pursued industrial policies by taxing trade and using state resources to build and subsidise a nascent domestic manufacturing industry. ${ }^{36}$ Nationalisation policies, whereby the government formed or bought stakes in foreign-owned corporations, also provided a means of indigenizing the economy, thereby reducing foreign ownership of productive resources. ${ }^{37}$ Big infrastructure projects, in trunk roads, power generation and port infrastructure, also featured strongly in early development plans.

Thus to reserve funds for 'development' became a prime budget objective. In budget speeches, economic analyses and development plans, officials show a preoccupation with shrinking the recurrent outlays to make fiscal space for investment. ${ }^{38}$ A World Bank report from 1977 noted that '[t]here is likely to be considerable resistance in Tanzania to any suggestion that the investment rate be reduced for the sake of macrofinancial balance. (...) it is clear from Tanzanian policy documents that maintenance of the investment rate is regarded as a principal indicator of commitment to development' ${ }^{39}$

The largely debt- and grant-financed development budget therefore drove up the debt stock, which with time translated into higher interest payments. As loans were denominated in foreign currency, currency depreciations also pushed the debt burden higher. By the 1980s debt payments began to crowd out capital spending. This process was particularly marked in Kenya, where subsidies and interest peaked at 30 per cent of spending in the early 1990s, displacing both capital and recurrent spending. Tanzania

\footnotetext{
${ }^{34}$ International Monetary Fund, 'Uganda: Recent economic developments’, p. 52.

${ }^{35}$ Cooper, Africa since 1940.

${ }^{36}$ Ibid.; Austin, 'The developmental state'; Adedeji, 'Comparative strategies'.

${ }^{37}$ Mamdani, Politics and class formation, p. 315.

${ }^{38}$ E.g.: Government of Tanganyika, 'Development plan for Tanganyika', pp. 9-12; Uganda, 'Sessional paper no.2 of 1962', p. 4.

${ }^{39}$ World Bank, 'Tanzania: Basic economic report', p. 93.
} 
also experienced a high debt burden with interest payments peaking at 18 per cent of expenditure, while Uganda's debt payments remained smaller as the country had less access to capital markets during Idi Amin's rule and started receiving debt relief earlier than its neighbours. ${ }^{40}$

Another important postcolonial expenditure shift was the growth in military spending. Under colonial rule the metropolis had effectively subsidized much of the defence of the colonies, as foreign policy and defence was an imperial matter rather than the responsibility of individual colonies. ${ }^{41}$ Domestic military spending began to grow in the independence period and escalated towards the end of the 1960s and 1970s in response to regional instability and growing domestic dissent. In Uganda the defence budget consumed almost a quarter of the government expenditure by the close of the civil conflict in 1986. Tanzania too, which fought a war against Uganda in 1978-9, saw its military spending spike and recurrent expenditure exceeded revenue for the first time in $1979 .{ }^{42}$ Kenya also faced growing instability on its northern border, although a stronger and larger military may also have served domestic purposes. Defence spending crowded out both recurrent and development spending.

A final budgetary change, not captured in the economic classification, was the rise in education spending. Table 1 estimates education expenditure as a share of total central government primary expenditure in Kenya and Uganda. The education share rose from 12 per cent in 1950 to a peak of 33 per cent of primary expenditure in 1999/2000 in Kenya, and from 9 per cent in 1950 to 27 per cent in 1999/2000 in Uganda. Literature on the colonial state has stressed the low priority given to African education in the first decades of colonial rule, which colonial governments (at least in British Africa) largely outsourced to religious missions. ${ }^{43}$ British colonial policy in Africa also discouraged the expansion of post-primary education, for fear that this would fuel nationalist resistance to colonial rule. ${ }^{44}$ These policies began to change slowly in the interwar period and more rapidly in the 1940s. Towards the end of the colonial era the East African governments began a rapid expansion of the education system which continued into the postcolonial era. Relative to their educational starting point, these countries undertook considerable investments in education, throwing doubt on Easterly and Levine's posited relationship between ethnic polarization and low educational attainment.

\section{[TABLE 1]}

Against a growing capital budget, growing military spending, and later a ballooning debt burden, the civilian wage budget fell as a share of total expenditure. As a share of GDP the wage bill remained relatively constant in Kenya and Tanzania while it declined in Uganda during the crisis decades. This relative decline in wage spending started in the 1960s, well before the economic crisis. Far from being a protected segment of the budget that drove up the deficit and crowded out more productive spending on public goods, in all three countries the wage bill contracted.

IV.

In light of these compositional changes to spending and rapid real expenditure rise and decline, public employment composition likewise changed. Given the supposed importance of public sector jobs to African political settlements and regime survival, this next section examines how the public sector labour force expanded. Was job creation concentrated in sectors amenable to patronage? Were public employees protected during the fiscal crises, and if not, how was the burden of job losses distributed?

\footnotetext{
${ }^{40}$ Birdsall, William, and Deese, 'Delivering on debt', Appendix C.

${ }^{41}$ Gardner, Taxing colonial Africa, Chapter 9.

${ }^{42}$ World Bank, 'Tanzania: Public expenditure review'.

${ }^{43}$ Frankema, 'The origins of formal education '; Gardner, Taxing colonial Africa.

${ }^{44}$ Mamdani, Define and rule.
} 
Figure 3 provides time series data on the public sector share of the labour force, disaggregated into four broad categories: general government, parastatals and state-owned enterprises, defence and the teaching force. As the military is excluded from most surveys on public employment, estimates for total military personnel are taken from the International Institute for Strategic Studies annual bulletin, available from 1971. The data quality for Uganda and Tanzania weakens in the 1980s and rests on interpolation in places. All assumptions underlying these series are discussed in Appendix S2.

In absolute terms employment grew rapidly after independence. The number of public sector employees tripled in Uganda, quadrupled in Kenya and increased by a factor of five in Tanzania between 1960 and 1990. However, all three countries experienced fast population growth over the same period and in relation to the size of the labour force the public employment growth was more modest and in line with growth rates in Europe, with an increase from roughly 4.5 per cent to 7 per cent in Kenya between 1960 and 1990, 2.5 per cent to 6.5 per cent in Tanzania, and 3.4 per cent to 4.5 per cent in Uganda. The Ugandan series exclude parastatal employment (due to the lack of data), but ad hoc measures suggest that parastatal employment was lower than in the neighbouring countries. ${ }^{45}$ Even at their peaks however, these levels of public employment were low by international standards and the public employment share then fell significantly in the 1990s ${ }^{46}$ By 2010 public sector employment in Kenya was 40 per cent lower than at independence, in Uganda 30 per cent lower, and in Tanzania on par with the level at independence.

Military personnel remained a small share of the total in Kenya and Tanzania, rising to a high of 4 per cent of all public employment in Kenya by the early 2000s, and peaking at 9 per cent in Tanzania following the Uganda-Tanzania war in 1979. In Uganda, unsurprisingly, the armed forces grew bigger, and reached a quarter of total public employment by the early 1990s.

\section{[FIGURE 3]}

Clearly then, these three countries could not afford the large public employee safety nets of richer countries, or direct buying of votes through jobs, as modelled by Robinson and Verdier. Even at their peak, governments employed only one in 15 to 20 active labour force participants. Other scholars have argued that patronage in Africa is high-level and selective, and focuses on distributing jobs or other benefits to strategic individuals and in-groups (often along ethnic lines), that help to defend the fragile regime. ${ }^{47}$ If this were so, we would expect to see growth in sectors amenable to discretionary job allocation and in politically strategic or ethnically favoured regions, while the subsequent cuts to employment would predominantly target politically marginalised groups. Examining employment composition on a sectoral, geographic and generational basis therefore sheds light on the ease with which public sector hiring could serve patronage purposes.

The sectoral public service divisions in Figure 3 show that most of the public employment growth was due to two factors: nationalisation policies, which brought a large share of industrial employment under state direction, and the growth in the teaching force. Parastatal employment shot up in the 1960s in Kenya and Tanzania when firms were nationalised or created (many were existing employees who were reclassified from private to public sector). These jobs may well have been used to facilitate redistribution, but it is hard to see this as the original intent of nationalisation policies, given the importance afforded to industrial policy across the globe in this era. Furthermore, parastatal growth

\footnotetext{
${ }^{45}$ Estimated at 54,000 in 1988, or 0.8 per cent of the labour force, see: World Bank, 'Uganda: Growing out of poverty', p. 104.

${ }^{46}$ See comparison with: Schiavo-Campo, de Tommaso, and Mukherjee, 'Government employment and pay' Table 3.

${ }^{47}$ For example: Lindemann, 'Elite bargains'.
} 
plateaued already in the late 1970s and dropped back down in the 1980s and 1990s as firms were privatized, suggesting that central governments had some degree of autonomy from pressures to indefinitely shield an inefficient and overstaffed parastatal sector.

The teacher share of employment in contrast continued to grow throughout the postcolonial period. The teacher share grew from between 12-16 per cent of general government employment in 1960 to 50 per cent of more by 2010. Consequently, the decline in public employment levels since the 1990s affected all major sectors except for the teaching force.

The Kenyan data also allows public employment to be disaggregated by industrial classification (Table 2). Consistent with the fall in parastatal employment, the largest employment declines in the 1990s and 2000s were in economic services, affecting industries such as agriculture, manufacturing, transportation (including port and railway administration) and construction. This is fully in line with neoliberal prescriptions, which argued that governments should allow private ownership of those industries subjected to market competition. ${ }^{48}$ Staffing levels in core public services (law and order, general government administration) remained relatively constant in nominal terms but fell slightly in relative terms, while staffing in education and health services increased in share.

If the government's primary use of the wage budget was to distribute patronage, this sectoral pattern is a surprising one. Teachers and other service providers are comparatively skilled cadres. Most teachers hold certificates and enter the teaching service upon completion of their training, which means that teaching jobs cannot be discretionarily allocated at whim to political favourites. Furthermore, in the first decades of independence all three governments put in place employment guarantees for graduates from teacher training colleges and medical schools, which meant that candidates were selected into these professions at a young age. Lastly, teachers, in particular, are spread across all regions and ethnic communities, which makes it unlikely that the teaching force will narrowly target a particular region.

Turning to data on geographic distribution of public sector jobs allows us to examine the evidence on geographic targeting of jobs directly. Table 3 estimates the public employment to population ratios across subnational regions and over time. Only fragmentary records of the regional breakdown of public employment are available, and the estimates therefore draw on a mixture of sources, including employment surveys, censuses and household surveys. These estimates therefore come with a considerable margin of error. In the Kenyan case, where administrative regions accord quite closely with ethnic divisions, districts have also been classified by main ethnic group, to give a sense of how public employment densities differ on an ethnic basis. Districts are classified according to its main ethnic group if more than 50 per cent of the population is of said ethnicity, while multi-ethnic Nairobi and Mombasa constitute a group of their own. ${ }^{49}$

This data shows little sign that the employment costs of adjustment were unfairly distributed geographically or that employment cuts disproportionately targeted marginalised regions or ethnic groups. The Kenyan results suggest that regional and ethnic equity in job distribution has in fact improved over time. The coefficient of variation in the ratio of public employees to 1,000 residents across Kenya's provinces and 'ethnic areas' has fallen substantially, largely due to the declining public employment shares in Nairobi and Mombasa. With the exception of the Somali, ethnic group differences in employment to population ratios are not enormous and show strong persistence over time,

\footnotetext{
${ }^{48}$ Pradhan, 'Evaluating public spending'.

${ }^{49}$ Method of aggregation explained in Appendix S2.
} 
despite Kenya's presidential transitions in 1978 and 2002 which led to a change the ethnicity of the president.

A calculation of the percentage reduction in the public employment ratio between 1985 and 2009, when public employment in Kenya was falling, shows that the burden of adjustment was shared across all provinces and ethnic areas, with the largest declines in the economic centres, Nairobi and Mombasa. Given the disproportionate share of parastatal and general administrative staff in the capital city and main port town, this is perhaps not so surprising. The Kalenjin and Kikuyu districts, from which Kenya's presidents hailed, ${ }^{50}$ show below average employment declines over the adjustment period, although some other groups show even smaller declines. This suggests that any protection from adjustment for coethnics of the president was mild at best. The clearest outlier, meanwhile, is the predominantly Somali, former North-Eastern Province, which has had an unusually low public employment to population share. However, the continued political insecurity in this region, refugee inflows from bordering Somalia, and high level of pastoralism (which makes educational supply harder), suggests that the drivers are rather more complicated than a simple story of patronage denied. Unreliable population estimates for this region also make the data trends particularly uncertain.

The data from Tanzania and Uganda is less robust and estimates from the 1990s and 2000s rest on relatively small sample household budget surveys. For ease of analysis, Tanzania's regions have been reclassified into larger units (using historical provincial borders), to give consistent borders over time and reduce the number of units of analysis. With these caveats, the data suggests that as in Kenya, the Tanzanian distribution of jobs grew more regionally equitable up until 2000, owing to the declining public employment share in Dar es Salaam and Tanga (which includes Kilimanjaro, one of the richest and most developed regions during the colonial era). ${ }^{51}$

The Ugandan data is disaggregated by Uganda's four regions in addition to Kampala. The general picture is consistent with that of Kenya and Tanzania. The main decline in jobs was in Kampala, while level differences across the remaining regions are small and volatile. There is no strong sign that the Northern and Eastern regions, where opposition to President Museveni's National Resistance Movement has been strong, were penalised. In fact, other research has shown that public employment levels in the early 2000s were unusually high in Uganda's conflict-affected regions. ${ }^{52}$

Other literature suggests that patronage may be linked to party membership more so than ethnicity. While historical data on party affiliation and sector of employment is limited, the Afrobarometer opinion surveys which started in the early 2000s allow for at least a single estimate. This survey asks respondents about their party affiliation as well as their occupation, making it possible to single out government workers and teachers, which combined constitute the majority of public sector employees. Counter to the prediction, in Uganda and Tanzania the surveyed government employees report lower levels of affiliation with the ruling party than the surveyed population as a whole, while in Kenya the groups are roughly equal. In none of the cases, however, are these differences statistically significant. ${ }^{53}$

\footnotetext{
${ }^{50}$ Presidents Kenyatta (1964-78) and Kibaki (2002-13) were of Kikuyu ethnicity, while President Moi (19782002) was of Kalenjin ethnicity.

51 The decline in West Lake is probably due to sampling error, given the rebound in the 2010 survey.

52 Simson, 'Ethnic (in)equality', pp. 17-8.

${ }^{53}$ Calculated by pooling Afrobarometer rounds 1, 2 and 3. Question asks whether respondent feels close to any party. In Kenya affiliation with the National Rainbow Coalition was $47 \%$ among government workers and $46 \%$ among others; in Tanzania affiliation with CCM was 49\% among government workers and 63\% among others; and in Uganda affiliation with the NRM was $23 \%$ among government workers and $34 \%$ among others.
} 
Lastly, we can also consider employment trends on a generational basis. In all three countries, the civil service reform programmes involved limited retrenchments. Most of the reduction in employment was achieved through voluntary redundancy schemes, retrenchment of those above retirement age, early retirement schemes and cleaning payrolls of 'ghost workers', alongside employment freezes and normal attrition. ${ }^{54}$ Uganda also retrenched most staff on casual contracts ('group employees') and Tanzania had a scheme to remove underperforming staff, but the numbers affected were small. Against an attrition rate of 4-5 per cent and a population growth rate of 3 per cent, this resulted in rapid reductions in the public employment to population ratio. Consequently, much of the reduction in staffing was achieved by limiting new hires, rather than firing existing employees. This suggests that governments sought to avoid making distributional choices.

In a sense therefore, at least in Kenya and Tanzania, the losers and winners were different generational groups, rather than regions or sectors. As has been shown in other studies, the formal job market tightened in the 1980s, for both skilled and unskilled employees. Studies of job prospects for recent graduates in Kenya found that job prospects worsened for those who graduated in the early 1980s relative to the $1970 \mathrm{~s},{ }^{55}$ while secondary school graduates faced tighter job markets already by the early 1970s. ${ }^{56}$ Conditional on skill, younger Kenyans and Tanzanians (if less so Ugandans) are therefore less likely to work for the state than their older compatriots. ${ }^{57}$ Concurrently, the public service grew more female, as female educational participation increased and as jobs shifted to sectors where women had a higher relative representation (such as education and healthcare). The share of women in Tanzania's public service rose from 6 per cent in 1965 to 40 per cent in 2012, and in Kenya from 8 per cent in 1965 to 37 per cent in $2009 .{ }^{58}$

Consequently, the greatest relative decline in the probability of holding public employment was felt by low-skilled, urban, male labour force participants, which are often thought to be the kinds of jobs over which politicians have most discretion and thus ability to practice patronage. Beyond the capital cities, the geographic distribution of employment did not change markedly, while jobs increasingly favoured comparatively skilled and female professions. While these trends do not rule out nepotistic or unmeritocratic practices within public sector recruitment, it shows that from the 1980s and onward the high-level allocation of wage resources on the whole constrained, rather than eased, the distribution of patronage.

V.

Not only the composition of employment, but also the private returns to public employment, changed over this period. This next section traces average wage developments and considers government tradeoffs between the level of employment and the level of pay. To the extent that public sector workers formed the leadership's clientelist base, we would expect some effort to protect the earnings of this social strata, to prevent a reduction in their loyalty to the political leadership. Was this the case? How

\footnotetext{
Significance of a government worker dummy on affiliation with ruling party was tested using a logistic regression, controlling for education, age, gender and urban/rural status.

${ }^{54}$ Lukumai, 'civil service reforms'; Sendyona, 'Public service'; Lorete, 'Kenya civil service reform'.

${ }^{55}$ Hughes, 'Fortunate few', pp. 586-87.

${ }^{56}$ Kinyanjui, 'Education'; Currie and Maas, 'Uganda's secondary school graduates'.

${ }^{57}$ Simson, 'Ethnic (in)equality', p. 13.

${ }^{58}$ Simson, '(Under)privileged bureaucrats', p. 74.
} 
did average public sector salaries compare to those in the private sector? How did policy documents and discourse motivate the employment and wage priorities of the government?

In constant terms, average public sector earnings oscillated over the second half of the $20^{\text {th }}$ century. Figure 4 shows the rise and decline of average real earnings in the public sector between 1960 and the present. It shows that formal sector workers received a wage dividend in the early independence era as average earnings rose in the 1960s while prices remained stable. After this, however, public sector wages declined steadily between the early 1970s until the early 1990s, with a fall of almost 70 per cent between peak and trough in Kenya, and almost 80 per cent in Tanzania. The Ugandan wage trend is calculated as a multiple of GDP per capita rather than in constant terms due to the lack of a reliable consumer price index for the mid-1980s to 1990s. It suggests an even steeper decline in Uganda, with public sector earnings falling by 90 per cent in relation to GDP per capita by the mid-1980s. Since the mid-1990s earnings have been recovering in all three countries. There is thus an inverse relationship between average earnings and the level of employment, with rapidly falling earnings at the time that employment was growing and vice versa.

\section{[FIGURE 4]}

At the same time as earnings fell, the educational level within the public service increased, as new employment in the postcolonial era disproportionately favoured teachers, nurses and other comparatively high-skilled professionals. The average earning declines therefore understate the true extent of the formal real wage falls, which were particularly severe for higher skilled staff. The base salary for a Kenyan director for instance, was KSh.6 million in 1961/2, valued in $2010 \mathrm{KSh} .{ }^{59}$ This had fallen to KSh.1.1 million by 2011/2, while the ratio between the director-level salary and the minimum wage fell from 30:1 to 10:1. ${ }^{60}$

Public sector salaries also fell in relation to average national earnings. The dotted line in Figure 4 shows how average household consumption shifted over the same time period, and reveals a milder decline and recovery. Average public sector earnings can be expressed as a multiple of average household consumption. In Kenya this ratio fell from a high of 1.8 to just below 1 in the mid-1990s, and in Tanzania from 1.8 in 1975 to under a half by the late 1980s. In Uganda it fell from 1.3 in 1967 to 0.1 in the late 1980s. At their lowest point, the average government pay check did not meet the expenses of an average household in any of the three countries.

It is possible that these earning declines are overestimated by the inclusion of 'ghost workers' on the payroll, i.e. non-existing staff who's earnings may have been redistributed to others. However, these 'ghost' salaries can only have had a marginal impact on average wage rates. Tanzania's civil service was later reduced by roughly 6 per cent through the identification of 'ghosts' (1993-99), and Uganda's by 13 per cent in the early 1990s (mostly in lower cadres), ${ }^{61}$ which yielded only modest savings relative to average earning declines.

However, the fall in real public sector earnings does not necessarily mean that candidates had rosier prospects in comparable private employment. Several studies have examined public-private wage premiums in eastern Africa, exploring the extent to which government offered a salary premium relative to private sector posts at the same skills level. Most find some evidence that they do, at least for lower

\footnotetext{
${ }^{59}$ Colony and protectorate of Kenya, '1961/62 estimates', p. 141.

${ }^{60}$ Republic of Kenya, '2011/12 estimates', p. 622.; minimum wages: Appendix S1. Based on salary of director for external trade, ministry of trade, vote R16.

${ }^{61}$ Lukumai, 'civil service reforms', p.42; Sendyona, 'Public service', p.94
} 
skilled employees. ${ }^{62}$ This paper will not add to the evidence on the size of sectoral pay premiums per se, but Figure 5 traces the average public: private earnings ratios over time in Kenya and Tanzania, which points to the likely direction of change of any public sector premium. On average, the publicprivate earnings gap decreased over time in Kenya and dropped below one in 1993. Tanzanian data is only available up until 1980, but similarly shows a downward trend in the public to formal sector wage ratio. While these ratios do not control for compositional changes to the public and private labour forces, average educational attainment appears to have grown faster in the public than in the private sector which suggests that the falling sectoral differential was not driven by changes to the relative sectoral skills composition. ${ }^{63}$

\section{[FIGURE 5]}

In part then, public employment growth was financed through a reduction in real and relative public sector wages. Comparing the movement in the level of employment with average real wage rates suggests that public employment policy across the region is characterised by three phases, similarly timed across the countries. The late colonial period and early independence era was characterised by wage growth and low public employment growth; the 1970s and 1980s by high employment growth and real earnings falls; and in the 1990s earnings began to recover, while the level of employment contracted. How did governments motivate these oscillating wage policies?

Several historical studies have examined colonial employment policies in the context of decolonisation, seeking to explain the rise in earnings and improved labour conditions for African employees in the 1950s and 60s. ${ }^{64}$ This literature has emphasised the growing political voice of African public sector workers. Real wages had fallen considerably during the Second World War and a series of strikes among dock workers, railway workers and other manual labourers in the second half of the 1940s and 1950s across cities in Africa threatened the colonial order. In response to this labour unrest and rising nationalist agitation, colonial governments sought to 'stabilize' the African formal labour force through the introduction of minimum wage legislation and responsible trade unionism. ${ }^{65}$ Concurrently, the middle and senior levels of the public services were gradually Africanized over the course of the decolonization period in preparation for independence. For Africans alone, real earnings therefore rose almost four-fold in Kenya and Tanzania and three-fold in Uganda between the late 1940s and early 1970s as African workers rose in the ranks and minimum wages were progressively raised. ${ }^{66}$

However, this state of affairs only lasted for a few years after independence. Average public sector earnings began to fall in the 1970s as government employment imperatives changed and fiscal conditions deteriorated. All three independent governments proved quick to temper the demands of wage earners by limiting the powers of labour movements. ${ }^{67}$ Starting in the 1960s, union powers were successively curbed. Tanzania abolished unions in $1964,{ }^{68}$ Uganda restricted union activities in 1964 and outlawed strike action in $1970,{ }^{69}$ while the Kenyan government made it virtually impossible for

\footnotetext{
${ }^{62}$ Lindauer and Sabot, 'Public/private wage differential'; KIPPRA, 'Public-private sector wage differentials'; Okurut and Ssewanyana, 'Determinants of wage earnings'.

${ }^{63}$ Simson, '(Under)privileged bureaucrats', p. 107.

${ }^{64}$ Bigsten, Income distribution and growth; Collier and Lal, Labour and poverty; Cooper, Decolonization; Freund, The African worker.

${ }^{65}$ Cooper, Decolonization; Weeks, 'Wage policy'; Freund, The African worker.

${ }^{66}$ Appendix S1.

${ }^{67}$ Cooper, Decolonization.

${ }^{68}$ Shivji, Class struggles in Tanzania.

${ }^{69}$ Mamdani, Politics and class formation.
} 
workers to strike in $1972 .{ }^{70}$ The number of man-days lost annually to strikes fell considerably shortly before real earnings began to decline. ${ }^{71}$

Governments justified these policies on equity grounds. Concerned that senior government wages were set too high on account of the inherited colonial wage scale, and because of worries that the public sector employment was contributing to urban-rural income differentials, governments sought to limit further wage increases. ' $[\mathrm{C}]$ reating more jobs for the unemployed must take precedence over increasing the incomes of those already employed', was the official position of the Kenyan government in $1967 .^{72}$ Julius Nyerere made a similar plea in his inaugural speech as President in 1962, emphasising the risk of tension between highly paid civil servants and the uneducated majority. ${ }^{73}$ When it came to salary adjustments moreover, policies stated that wages of lower-paid employees were to be raised more than those at the top, in an effort to compress the large wage spread within the public service.

In Kenya in particular, the policy discourse from the early 1970s was strongly shaped by urban unemployment concerns, particularly unemployment among secondary school leavers. ${ }^{74}$ A series of tripartite agreements in Kenya (1964, 1970 and 1979) bound the government and private sector to increase the number of jobs by a set percentage in exchange for wage restraint on the part of trade unions, with the explicit aim of producing jobs for the unemployed..$^{75}$ While the actual impact of these agreements has been debated ${ }^{76}$ they are a testament to how politically important the government perceived the unemployment problem to be.

The Kenyan government also undertook periodic civil service wage reviews, which laid the basis for any adjustments to the nominal civil service wage scale. From the late 1970s these reports make clear that the government acknowledged that salary adjustments would not fully compensate staff for the rapid rate of inflation, and sought to the extent possible, to offer greater protection to those at the bottom of the wage distribution. ${ }^{77}$ Tanzania introduced a public sector wage freeze between 1975-80, during a period of high inflation, which resulted in rapid real earning declines.$^{78}$ Uganda undertook no systematic adjustment of public sector wages between the late 1960s and early 1990s despite rapid erosion of wages. Consequently, Uganda's wage declines were particularly severe. By 1990 the base pay for an entry-level degree-holder was US\$7 per month, and a Permanent Secretary officially earned US\$23. ${ }^{79}$

This approach to wage setting had run its course by the late 1980s. Policy discourse in East Africa shifted again and began to emphasise the unsustainable rate of employment expansion and the negative effects of wage falls on worker morale and effort. ${ }^{80}$ Reforms started cautiously with employment freezes and other means of curbing new hires. From the late 1980s and on IMF and World Bank programmes across the region commonly included structural benchmarks related to restraining the wage bill and size of the civil service. Donor-supported civil service reform programmes were explicitly designed to reduce staffing numbers to finance increases in salaries, which both governments and donors agreed

\footnotetext{
${ }^{70}$ Bigsten, Education and income determination.

${ }^{71}$ Simson, '(Under)privileged bureaucrats', p. 83.

72 Government of Kenya, 'Sessional paper no. 10 of 1967 ', para 8.

${ }^{73}$ Nyerere, 'President's inaugural address', pp.179-80.

74 Abernethy, 'Bureaucratic growth'; Cohen, 'Importance of public service reform', p. 455.

${ }^{75}$ Mukui, '1979 tripartite agreement'.

${ }^{76}$ Ibid., p. 563.

77 Government of Kenya, 'Sessional paper no.10 of 1980', para 48; Kenya, 'Civil service salaries review committee 1985 ', pp. 38-41.

${ }^{78}$ Valentine, 'Government wage policy'.

${ }^{79}$ Sendyona, 'Public service', p. 90.

${ }^{80}$ Example: Government of Kenya, 'Budget speech $1984 / 85$ ', p. 5.
} 
had fallen too low. ${ }^{81}$ In tandem all three governments initiated programmes to reform the parastatal sector, with long-running privatization programmes that reduced the number of parastatal staff. Furthermore, political reforms and democratization led to improved labour rights and some resurgence in strike action.

Consequently, salaries were successively increased over the course of the 1990s and 2000s, resulting in improvements in real earnings, although some of the increase in average earnings was also due to the disproportionate number of retrenchments in the lower cadres. Adjusting for skill, base wages in 2010 for senior staff remained below the levels of the 1960s.

This examination of official public sector wage policies reinforces the quantitative findings: for much of the postcolonial era, protecting the living standards of public servants was not a key budget priority. The wage budget remained a constant or falling share of spending, and during the first decades of independence all three governments explicitly prioritized employment growth over the protection of the wages of those already in employment. If these public sector workers were the clients of political patrons, who in exchange for a salary delivered political support for the incumbent, then this choice is puzzling. It seems likely to have weakened the loyalty of the regime's core support base. Furthermore, this policy was reversed at roughly the same time in all three countries with the advent of structural adjustment, when, with donor encouragement, governments rationalised or froze public employment to raise pay. Ironically, earnings increased and labour rights improved during the neoliberal era, under the watchful eye of the IMF and World Bank.

VI.

In conclusion, trends in public expenditure and employment in Kenya, Tanzania and Uganda offer a window onto central government expenditure prioritization, decision-making and constraints in three countries often described as patronage-afflicted. This perspective helps to contextualise debates about counterfactual policy paths and evaluate government policy choices in relation to external economic constraints and global policy paradigms.

Economic historians of African colonialism have long stressed that colonial policy was intimately tied to resource constraints. ${ }^{82}$ Unsurprisingly, these constraints continued to shape the policy space after independence. As in other regions of the world, the Kenyan, Tanzanian and Ugandan state expenditure and deficits expanded in the 1960s and 1970s during a period of high economic growth and global optimism about future prosperity. Revenue and expenditure then plateaued or fell in the 1980s, or earlier in the Ugandan case, as growth slowed. In real terms the resulting falls in spending were staggering. Using a consumer price index to deflate public expenditure shows that expenditure per capita more than halved over the course of the 1980s.

This long-term expenditure perspective also contradicts the common claim that African postcolonial states prioritized consumption, and particularly employment, over other forms of spending. The three case study governments initially prioritized the development budget over recurrent needs, and subsequently the military and debt service obligations over the former. The wage bill consequently fell as a share of expenditure. The level of employment continued to grow for slightly longer than expenditure, but declined sharply in the 1990s as fiscal conditions bottomed out. With the recovery in growth in the 2000s, the employment levels stabilized and has recently begun to rise once more. Within the wage budget, frontline service provision such as education and to a lesser extent health, claimed an

\footnotetext{
${ }^{81}$ Langseth, 'Uganda civil service reform'; Teskey and Hooper, 'Tanzanias civil service reform'; Lorete, 'Kenya civil service reform'.

${ }^{82}$ Gardner, Taxing colonial Africa.
} 
increased budget share. These spending shifts coincided with changing global development paradigms, from a focus on industrial policy and large infrastructural investments in the postwar era, to an emphasis on basic service delivery in the 1990s and 2000s.

Country context also clearly mattered, but the most extreme case of state mismanaged and dysfunction - Uganda - was also the state with the greatest neglect of its public servants. On the basis of these three cases alone the correlation appears to run in the opposite direction of that proposed in the structural adjustment and patronage literature. It was the country with the largest government wage bill and highest average earnings - Kenya - that experienced the milder economic contraction in the $1980 \mathrm{~s} .{ }^{83}$ Nor is there any clear relationship between ethnic polarization and spending on employment. Despite Tanzania's stronger national cohesion and weaker salience of ethnicity, it saw the sharpest increase in public employment after independence.

With these growing pressures on the budget, real earnings in the public sector fell sharply between the 1970s and 1990s. As deficits widened, the wage bill was held in check through high inflation which eroded real earnings and reduced the value of a government pay check relative to average national income and average earnings in the formal private sector. Informal rents and other means of compensating staff for falling wages may have off-set some of the decline in wages, but in the context of a rapidly shrinking resource envelope such compensation could only have been partial. There may well have been pockets or individuals within the public service who remained insulated from these shocks, but many qualitative studies and reports testify to a fall in living standards in the 1980s and 1990s for the average of public sector worker. In response, employees are thought to have diversified their economic activities by straddling several economic sectors to hedge risk and make ends meet. ${ }^{84}$ The international donor community came to lament the crisis in pay, and with it the erosion in staff effort and discipline, rather than the protection of a supposedly privileged public sector class. ${ }^{85}$

Given these constraints and conditions, should we expect that expenditure policies in countries such as Kenya, Tanzania and Uganda would have looked different in the absence of patronage pressures? With the benefits of hindsight, what could or should these three governments have done differently?

In retrospect it seems obvious that the countries would have benefitted from restraining the nominal growth in public employment earlier than they did. This could have ameliorated the extreme wage declines in the 1980s and 1990s which proved slow and difficult to correct. However, to attribute this failing to patronage seems unwarranted as it is perfectly plausible that governments allowed job growth to continue because it sought to expand service delivery or feared the destabilising consequences of unemployed graduates. Furthermore, if savings on employment were used to stabilize wages, they would not have affected the investment level anyhow, which is the main trade-off that concerns Englebert, Acemoglu and Robinson and other analysts of Africa's patronage politics. In addition, when public employment was eventually rationalised in the 1990s, governments seem to have followed a path of least resistance rather than targeting these employment cuts at specific constituencies. Employment was rationalised through largely passive means, including normal attrition, employment freezes and voluntary redundancies.

A large literature has criticized African nationalisation policies of the 1960s and 1970s, mismanaged industrial policy, and the excessive borrowing used to finance it. There may be much to learn from these failed industrialisation efforts, but in the context of a global enthusiasm for state-led development and

\footnotetext{
${ }^{83}$ See also: Goldsmith, 'Africa's overgrown state'; Rodrik, 'What drives public employment'.

${ }^{84}$ Githinji, Ten millionaires; Chew, 'Internal adjustment', p.1099.

${ }^{85}$ Lindauer, Rehabilitating government.
} 
prerogatives to reduce foreign ownership of industry, these choices are hardly unique or surprising, and require no patronage framework to explain them. ${ }^{86}$

Some have argued that Kenya (in particular) over-spent on education, and should have reduced the pace of educational expansion in the interest of fiscal stability and capital investment. ${ }^{87}$ Yet education is perhaps the most broad-based of all social programmes in Africa and has strong developmental rationale. From the 1990s moreover, the international donor community strongly encouraged the expansion of basic education and rapid growth in the teaching force.

All else being equal, lower spending on the military would have freed resources for developmental purposes, but to attribute military escalation to a patronage logic stretches the concept in rather a different direction, as investments in military force is surely the opposite of governance through pork barrel co-optation. In fact, several recent papers posit civil wars or coups as precisely what governance through patronage seeks to avert. ${ }^{88}$

A related question, that deserves treatment in its own right, is whether patronage or other governance weaknesses inhibited taxation and encouraged a reliance on foreign borrowing. Yet it is striking that the revenue to GDP ratio in Kenya and Tanzania fell in the context of structural adjustment reforms, rather than preceding them.

In the search for long-standing institutional explanations for Africa's governance weaknesses and economic underperformance, many scholars have dismissed official government policies and pronouncements as smokescreens for the opaque political bargaining that informally dictate the resource distribution. ${ }^{89}$ This article cautions that we shouldn't be too quick to dismiss the official story line. A closer look at public expenditure patterns in the early independence era shows them to be quite consistent with official policy and rhetoric. They testify to the importance given to industrial development, educational expansion and military autonomy; they show the emphasis placed on expanding public employment rather than protecting those already in government jobs; and they suggest a considerable ambivalence towards the high-wage legacy of the late colonial era. Kenya, Tanzania and Uganda are perhaps better testaments to the difficulties of having a proactive policy agenda - whether developmental or patrimonial - in a poor, militarily insecure and economically undiversified country caught in economic headwinds.

\footnotetext{
${ }^{86}$ See for instance: Clapham, 'Governmentality', pp. 815-6.

87 World Bank, Cost-benefit analysis.

${ }^{88}$ Francois et al., 'How is power shared', p.467.

${ }^{89}$ For a recent restatement, see: Andrews, Pritchett and Woolcock, 'Escaping capability traps'.
} 


\section{Kenya}

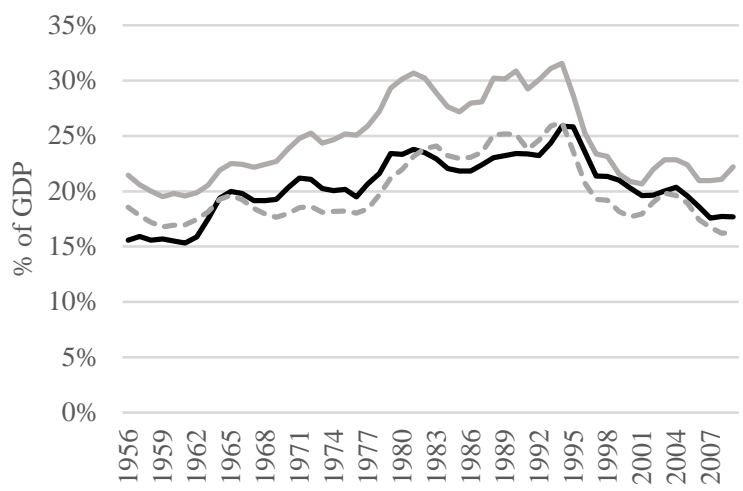

- General govt revenue to GDP (excl. grants)

General govt expenditure and net lending to GDP

- Recurrent expenditure only

\section{Tanzania}

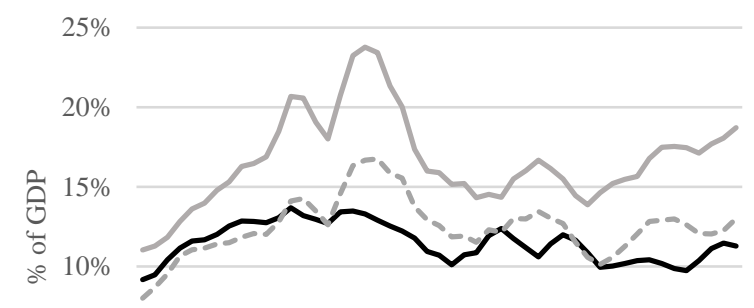

$5 \%$

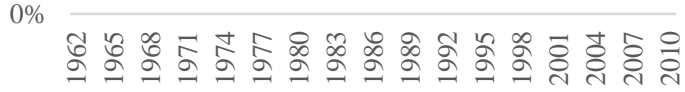

- General govt revenue to GDP (excl. grants)

- General govt expenditure and net lending to GDP

---- Recurrent expenditure only

\section{Uganda}

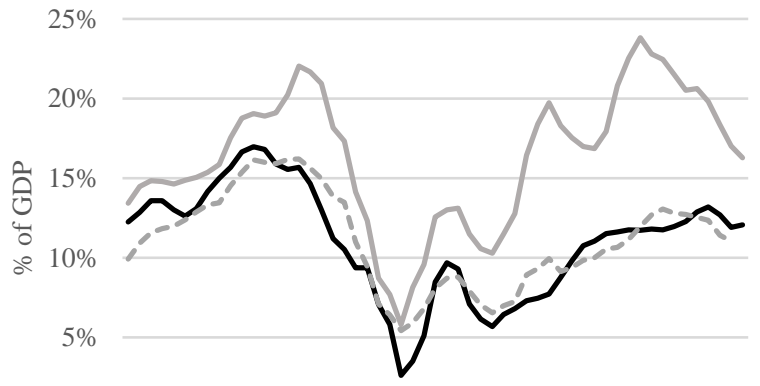

$0 \%$

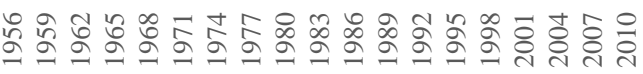

General govt revenue to GDP (excl. grants)

General govt expenditure and net lending to GDP

$-\infty-\infty$ Recurrent expenditure only
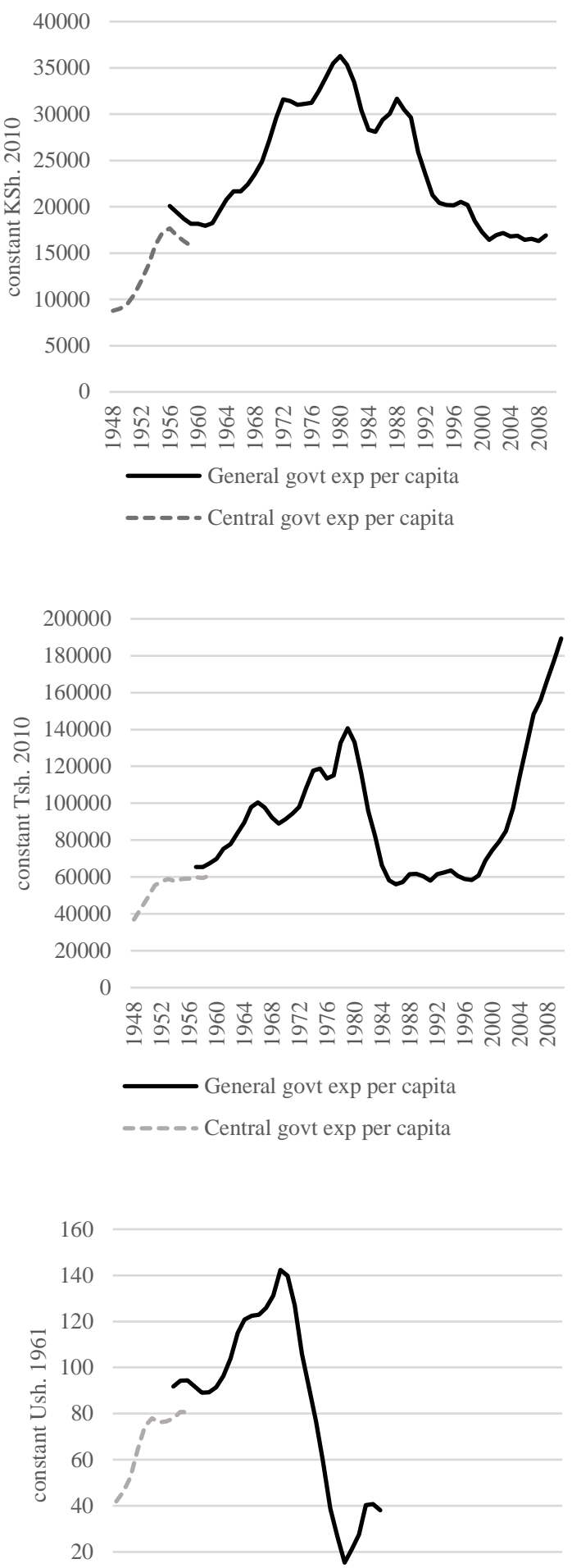

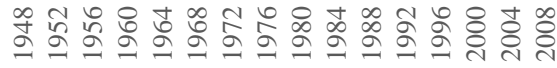

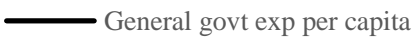

$-\infty-\infty$ Central govt exp per capita

Figure 1. General government revenue, expenditure, 1950s - 2010

Notes: Smoothed using 3-year moving average.

Sources: Appendix S1. 
Kenya

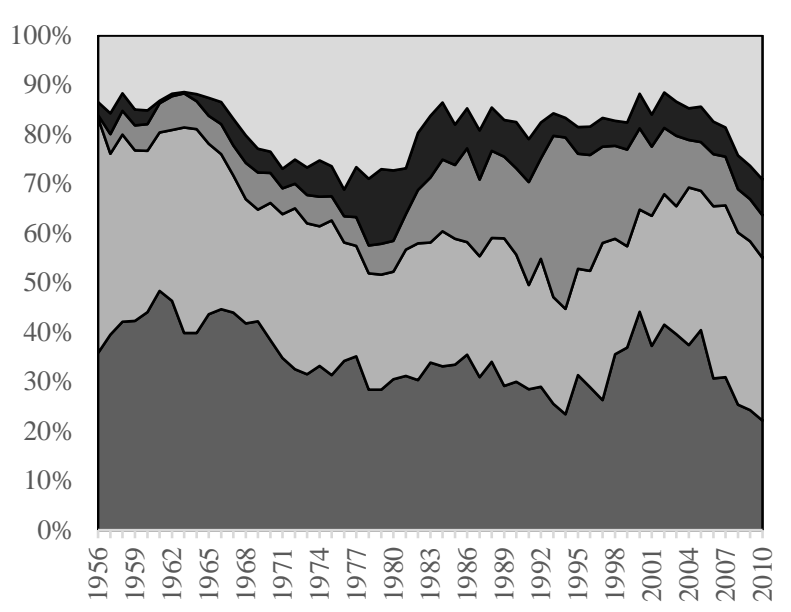

Composition of general government expenditure, $\%$ of total

Tanzania

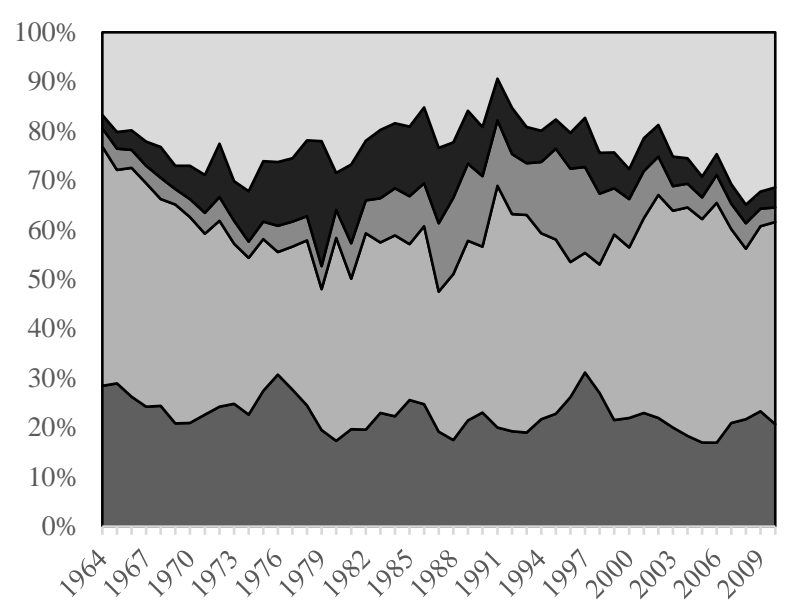

Uganda

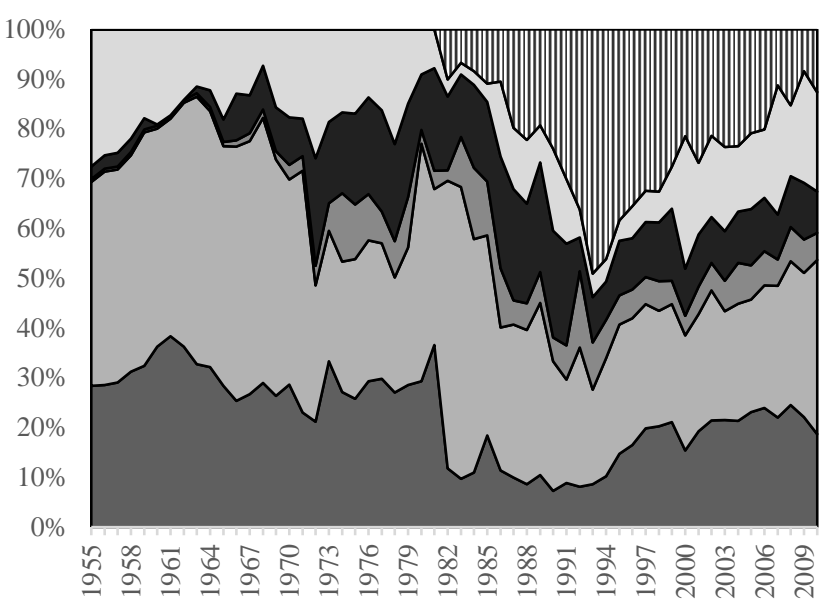

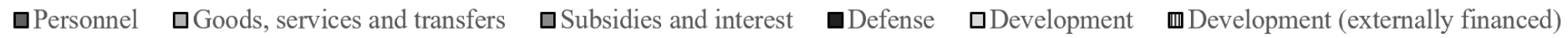

Composition of general government expenditure, \% of GDP
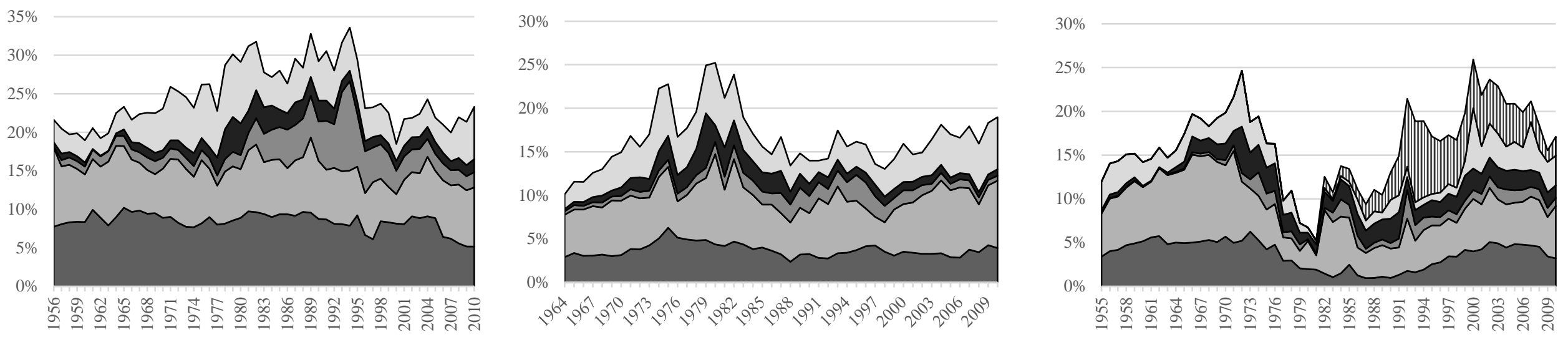

Figure 2. Government expenditure by economic classification, c.1960 - 2010

Sources: Appendix S1. 


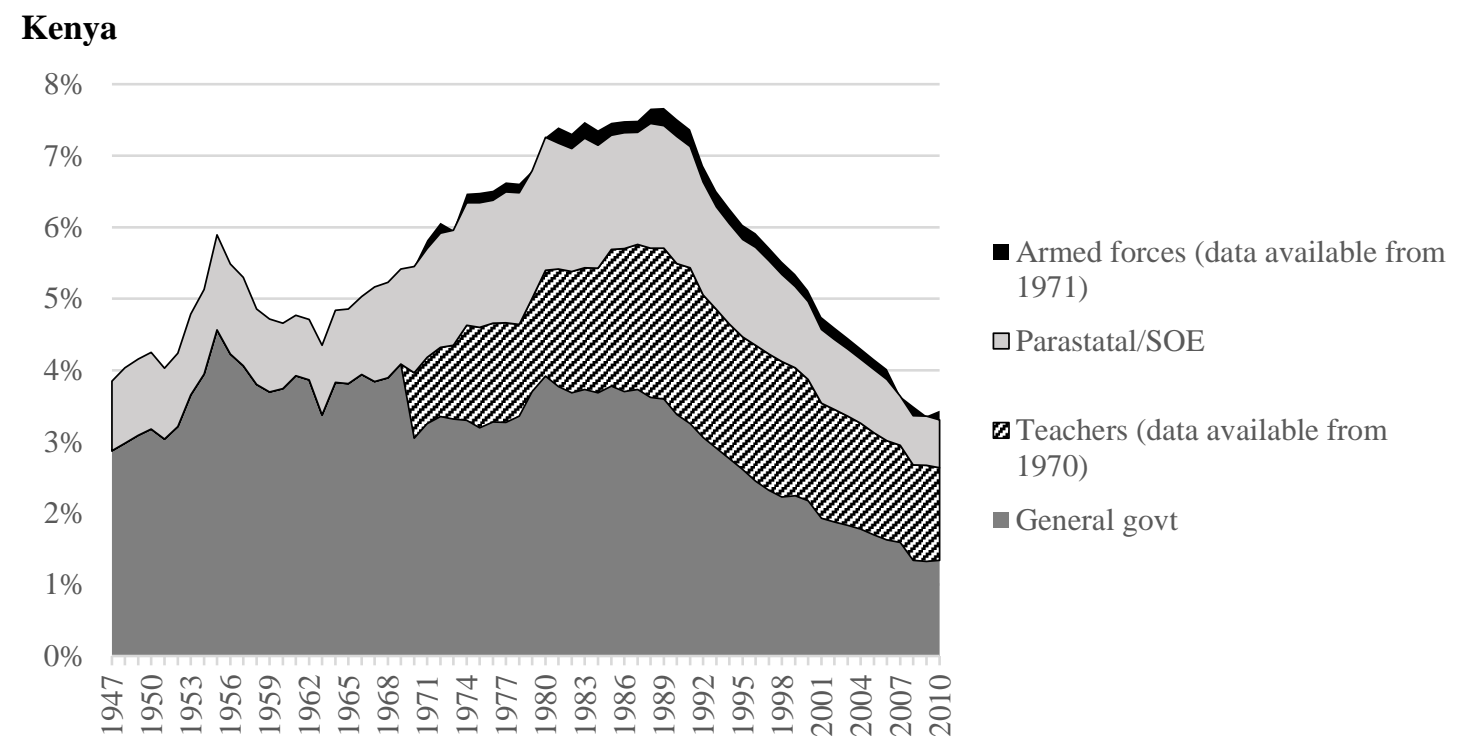

\section{Tanzania}

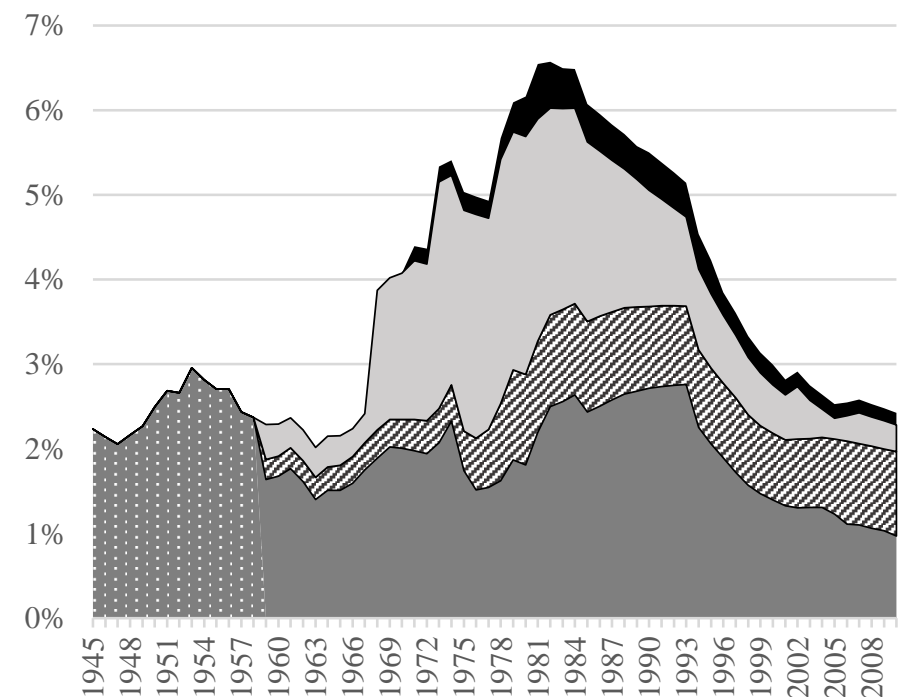

- Armed forces (data available from 1971)

口Parastatal/SOE

Teachers

- General govt

w Public employment (total)

\section{Uganda}

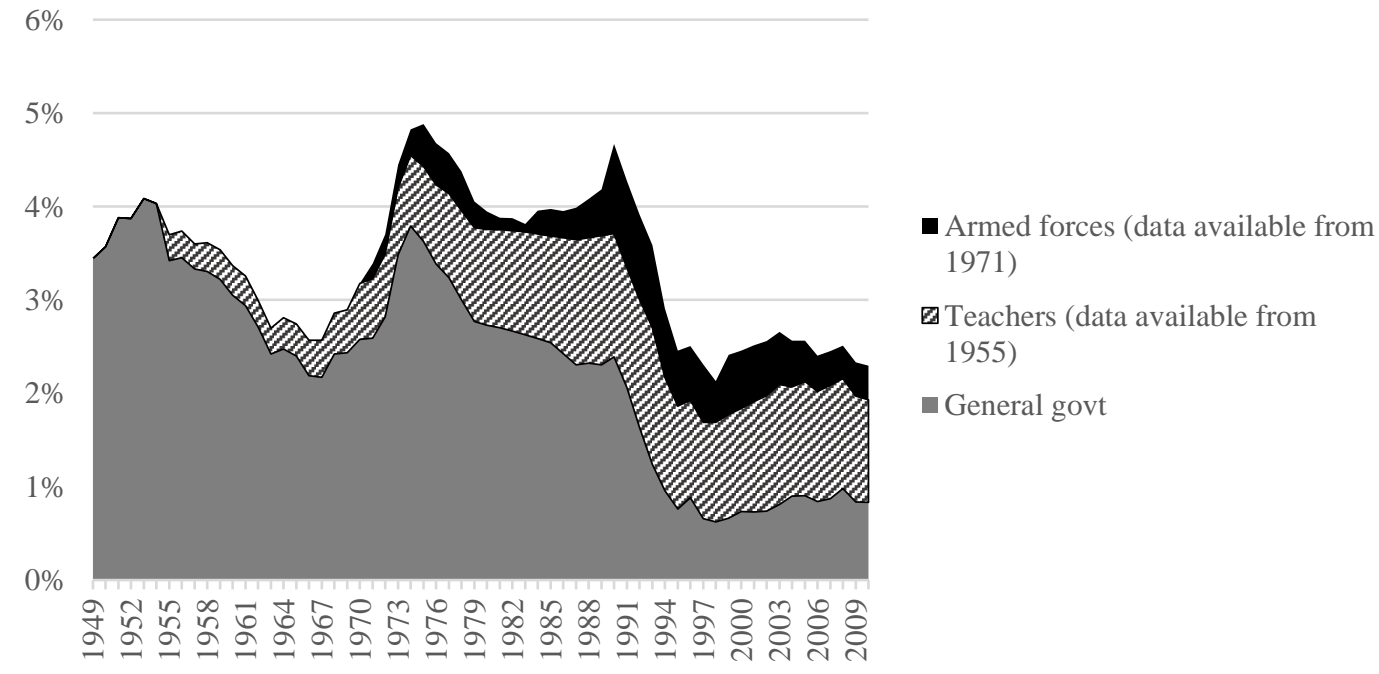

Figure 3. Public sector employment as \% of labour force, 1940s - 2010

Sources: Appendix S1. 


\section{Kenya}

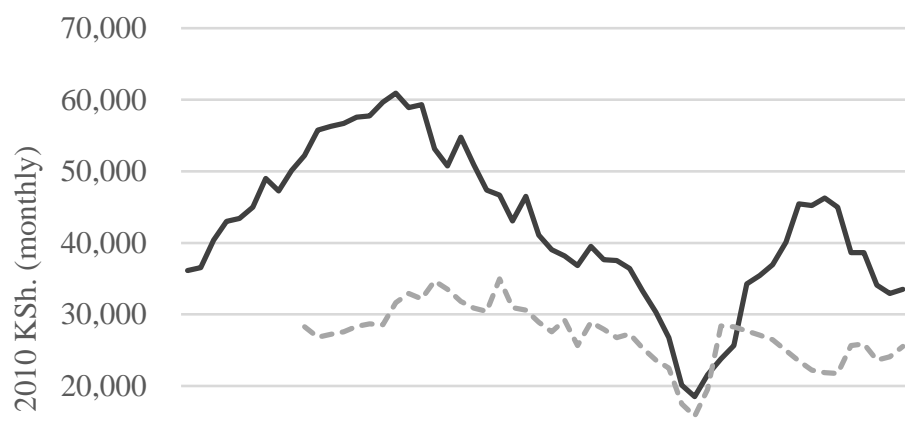

- Average public sector earnings

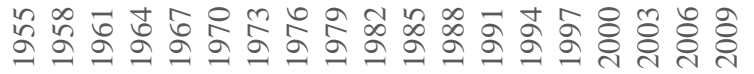

\section{Tanzania}

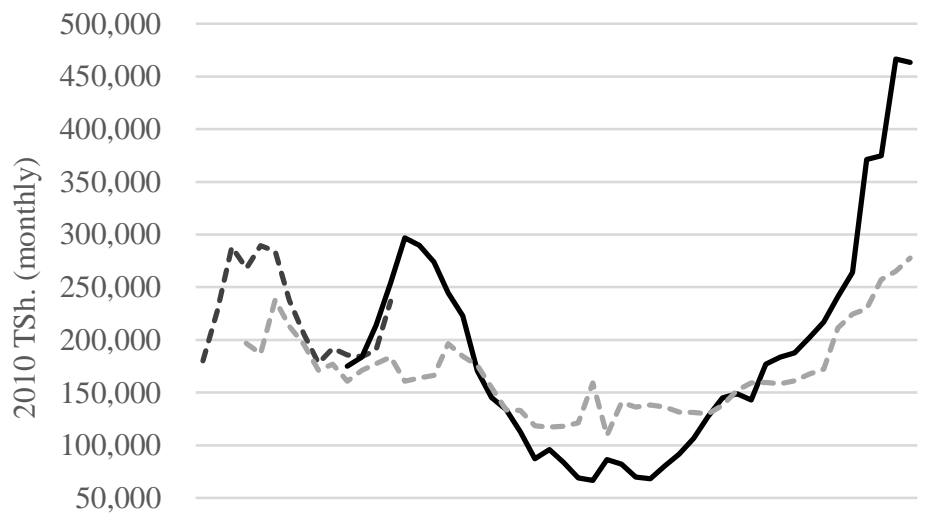

---Average government earnings (EES)

Average household consumption expenditure

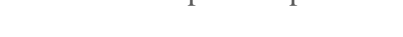
- Average government earnings (payroll and public expenditure reports)
$-\infty-\infty$ Average household consumption expenditure

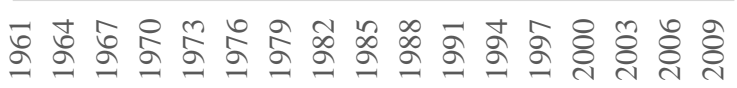

Uganda (Note: Average earnings as a multiple of GDP per capita)

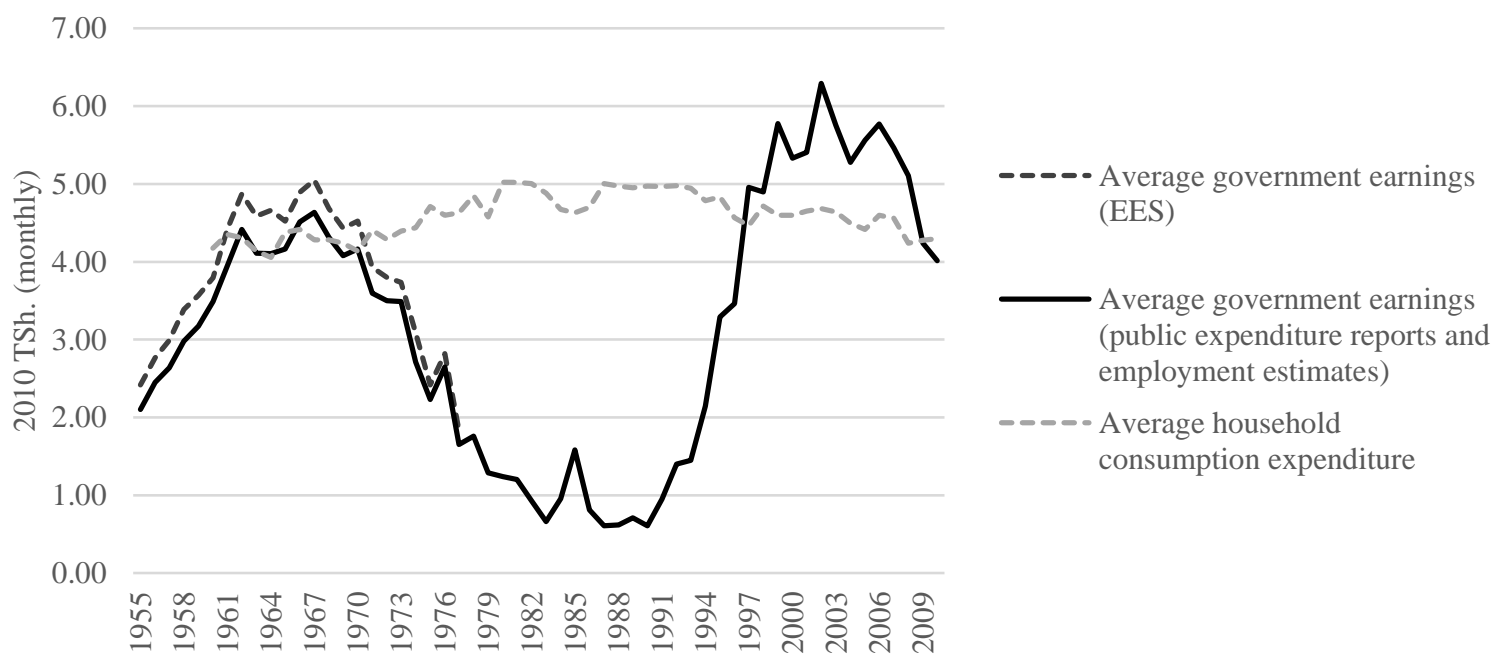

Figure 4. Average real monthly earnings in the public sector compared to average household consumption expenditure, 2010 prices

Sources: Appendix S1.

Note: Constant average household size of 5 assumed. 
Kenya

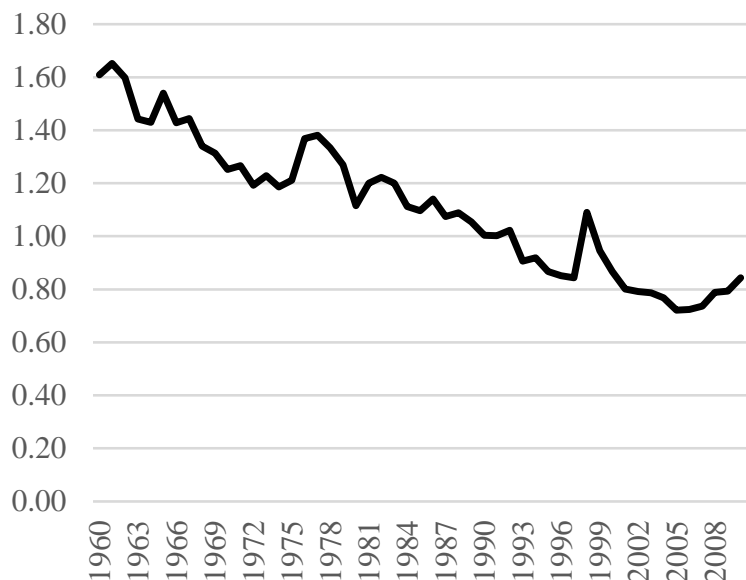

_ Average govt wage as multiple of formal private sector wage
Tanzania

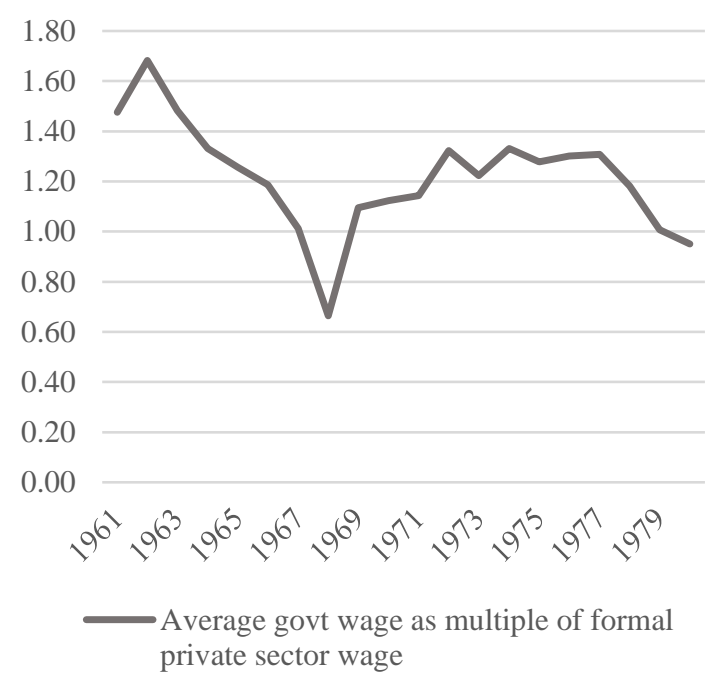

Figure 5. Average government earnings as a multiple of average private/formal sector earnings Sources: Appendix S1. 
Table 1. Education expenditure as share of primary $^{a}$ central government expenditure, $\%$ total

\begin{tabular}{|l|c|r|r|r|r|r|}
\hline & $\begin{array}{c}1950 \\
\text { Recurrent only }\end{array}$ & $\mathbf{1 9 6 0 / 6 1}$ & $\mathbf{1 9 6 9 / 7 0}$ & $\mathbf{1 9 7 9 / 8 0}$ & $\mathbf{1 9 8 9 / 9 0}$ & \multicolumn{1}{|c|}{$\mathbf{1 9 9 9 / 0 0}$} \\
\hline Kenya & $10 \%$ & $17 \%$ & $25 \%$ & $20 \%$ & $26 \%$ & $33 \%$ \\
Uganda & $9 \%$ & $22 \%$ & $20 \%$ & $27 \%$ & - & $27 \%$ \\
\hline
\end{tabular}

a. Primary expenditure $=$ total expenditure excluding interest payments

b. 1961/62 for Uganda

Sources: Appendix S1.

Table 2. Kenya: public sector employment by industry

\begin{tabular}{|l|r|r|r|r|r|}
\hline Total employment & $\mathbf{1 9 7 2}$ & $\mathbf{1 9 8 0}$ & $\mathbf{1 9 9 0}$ & $\mathbf{2 0 0 0}$ & $\mathbf{2 0 0 8}$ \\
\hline Agriculture & 48,973 & 58,861 & 59,888 & 60,919 & 50,967 \\
Mining and Quarrying & 492 & 631 & 679 & 664 & 657 \\
Manufacturing & 17,669 & 29,852 & 41,544 & 35,777 & 27,133 \\
Electricity and Water & 5,124 & 10,030 & 21,924 & 21,232 & 17,027 \\
Construction & 14,179 & 31,457 & 34,476 & 26,265 & 19,852 \\
Wholesale and Retail Trade, & & & & & \\
Restaurants and Hotels & 1,619 & 4,507 & 9,393 & 6,382 & 6,021 \\
Transport and Communications & 27,342 & 31,163 & 48,235 & 39,729 & 37,319 \\
Finance, Insurance, Real Estate and & & & & & \\
Business Services & 2,723 & 7,821 & 17,928 & 16,159 & 14,193 \\
Government services & 23,486 & 41,883 & 80,758 & 60,757 & 42,112 \\
Law and order & 32,093 & 40,632 & 63,433 & 61,910 & 51,342 \\
Education services & 66,953 & 135,563 & 211,280 & 254,336 & 248,738 \\
Medical, dental and other health & & & & & \\
services & 21,303 & 34,097 & 47,012 & 57,256 & 59,143 \\
Other services & 25,002 & 44,008 & 55,293 & 51,090 & 47,345 \\
\hline Total & $\mathbf{2 8 6 , 9 5 8}$ & $\mathbf{4 7 0 , 5 0 5}$ & $\mathbf{6 9 1 , 8 4 3}$ & $\mathbf{6 9 2 , 4 7 6}$ & $\mathbf{6 2 1 , 8 4 9}$ \\
\hline \% share of total & & & & & \\
Agriculture & $17 \%$ & $13 \%$ & $9 \%$ & $9 \%$ & $8 \%$ \\
Mining and Quarrying & $0 \%$ & $0 \%$ & $0 \%$ & $0 \%$ & $0 \%$ \\
Manufacturing & $6 \%$ & $6 \%$ & $6 \%$ & $5 \%$ & $4 \%$ \\
Electricity and Water & $2 \%$ & $2 \%$ & $3 \%$ & $3 \%$ & $3 \%$ \\
Construction & $5 \%$ & $7 \%$ & $5 \%$ & $4 \%$ & $3 \%$ \\
Wholesale and Retail Trade, & & & & & \\
Restaurants and Hotels & $1 \%$ & $1 \%$ & $1 \%$ & $1 \%$ & $1 \%$ \\
Transport and Communications & $10 \%$ & $7 \%$ & $7 \%$ & $6 \%$ & $6 \%$ \\
Finance, Insurance, Real Estate and & & & & & \\
Business Services & $1 \%$ & $2 \%$ & $3 \%$ & $2 \%$ & $2 \%$ \\
Government services & $8 \%$ & $9 \%$ & $12 \%$ & $9 \%$ & $7 \%$ \\
Law and order & $11 \%$ & $9 \%$ & $9 \%$ & $9 \%$ & $8 \%$ \\
Education services & $23 \%$ & $29 \%$ & $31 \%$ & $37 \%$ & $40 \%$ \\
Medical, dental and other health & & & & & \\
services & $7 \%$ & $7 \%$ & $7 \%$ & $8 \%$ & $10 \%$ \\
Other services & $9 \%$ & $9 \%$ & $8 \%$ & $7 \%$ & $8 \%$ \\
\hline La & & & & &
\end{tabular}

a. Law and order includes civilian defence personnel, military is excluded.

Sources: Kenya, Statistical Abstracts, 1976, 1981, 1992, 2002, 2010, 2011. 
Table 3: Regional distribution of public sector employment, various years, 1960s-2000s

\section{Kenya}

\begin{tabular}{|c|c|c|c|c|c|c|c|c|c|}
\hline \multirow{2}{*}{$\begin{array}{l}\text { Main ethnic group } \\
\text { in district }^{\mathrm{a}}\end{array}$} & \multicolumn{4}{|c|}{$\begin{array}{c}\text { Public employees per } 1,000 \\
\text { people }\end{array}$} & \multicolumn{4}{|c|}{ Share of total public jobs } & \multirow{2}{*}{ 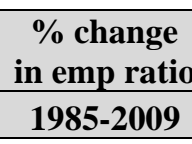 } \\
\hline & 1972 & 1981 & 1985 & 2009 & 1972 & 1981 & 1985 & 2009 & \\
\hline Kalenjin & 17.9 & 20.8 & 22.3 & 19.3 & $9 \%$ & $9 \%$ & $9 \%$ & $14 \%$ & $-14 \%$ \\
\hline Kamba & 11.5 & 18.6 & $18.5^{\mathrm{c}}$ & 17.2 & $5 \%$ & $6 \%$ & $6 \%$ & $7 \%$ & $-7 \%$ \\
\hline Kikuyu & 28.4 & 28.2 & 30.3 & 23.8 & $23 \%$ & $19 \%$ & $19 \%$ & $21 \%$ & $-21 \%$ \\
\hline Luhya & 13.6 & 23.1 & 27.4 & 14.9 & $8 \%$ & $11 \%$ & $12 \%$ & $11 \%$ & $-46 \%$ \\
\hline Luo & 12.5 & 19.7 & 23.9 & 16.2 & $7 \%$ & $8 \%$ & $9 \%$ & $8 \%$ & $-32 \%$ \\
\hline Meru & 13.5 & 15.0 & 16.1 & 15.9 & $3 \%$ & $3 \%$ & $3 \%$ & $4 \%$ & $-2 \%$ \\
\hline Other & 14.1 & 19.8 & 21.2 & 13.6 & $11 \%$ & $12 \%$ & $12 \%$ & $13 \%$ & $-36 \%$ \\
\hline Somali & 9.4 & $15.0^{\mathrm{b}}$ & $20.3^{b}$ & 5.7 & $1 \%$ & $1 \%$ & $2 \%$ & $2 \%$ & $-72 \%$ \\
\hline Nairobi \& Mombasa & 108.5 & 118.3 & 106.1 & 37.4 & $33 \%$ & $32 \%$ & $28 \%$ & $21 \%$ & $-65 \%$ \\
\hline $\begin{array}{l}\text { Natl. average } \\
\text { Natl. average, excl. }\end{array}$ & 23.4 & 29.2 & 30.1 & 18.9 & & & & & \\
\hline Nairobi and Momb. & 16.8 & 23.0 & 23.4 & 16.7 & & & & & \\
\hline$C V$ & 1.24 & 1.07 & 0.89 & 0.48 & & & & & \\
\hline Province & 1972 & 1981 & 1985 & 2009 & 1972 & 1981 & 1985 & 2009 & 1985-2009 \\
\hline Nairobi & 111.4 & 123.9 & 113.4 & 38.5 & $23 \%$ & $24 \%$ & $22 \%$ & $17 \%$ & $-66 \%$ \\
\hline Central & 23.1 & 24.6 & 26.1 & 23.1 & $15 \%$ & $13 \%$ & $13 \%$ & $14 \%$ & $-11 \%$ \\
\hline Nyanza & 11.9 & 18.4 & 22.1 & 16.1 & $9 \%$ & $11 \%$ & $12 \%$ & $12 \%$ & $-27 \%$ \\
\hline Western & 11.7 & 19.7 & 25.3 & 14.3 & $6 \%$ & $8 \%$ & $10 \%$ & $8 \%$ & $-44 \%$ \\
\hline Coast & 38.1 & 42.9 & 37.5 & 19.2 & $14 \%$ & $13 \%$ & $11 \%$ & $9 \%$ & $-49 \%$ \\
\hline Rift Valley & 23.2 & 26.2 & 27.4 & 18.2 & $20 \%$ & $19 \%$ & $20 \%$ & $25 \%$ & $-33 \%$ \\
\hline Eastern & 14.1 & 18.8 & $19.9 * *$ & 17.4 & $11 \%$ & $11 \%$ & $11 \%$ & $14 \%$ & $-13 \%$ \\
\hline North Eastern & 9.4 & $16.3^{*}$ & $20.3^{*}$ & 5.7 & $1 \%$ & $1 \%$ & $2 \%$ & $2 \%$ & $-72 \%$ \\
\hline Natl. average & 23.4 & 29.2 & 30.1 & 18.9 & & & & & \\
\hline$C V$ & 1.12 & 1.00 & 0.86 & 0.49 & & & & & \\
\hline
\end{tabular}

a. See Appendix S2 for ethnic coding of districts, p. 14

b. Population estimates adjusted to account for under-enumeration in 1989.

c. Adjustment due to apparent reporting error in 1985.

Sources: 1972-85: Kenya, Employment and earnings; 2009: Minnesota Population Center, '2009 census'. 


\section{Tanzania}

\begin{tabular}{|c|c|c|c|c|c|c|c|c|c|c|c|}
\hline \multirow{2}{*}{$\begin{array}{l}\text { Historical } \\
\text { provinces }^{a}\end{array}$} & \multicolumn{5}{|c|}{$\begin{array}{c}\text { Government employees }{ }^{\mathrm{b}} \text { per } 1,000 \\
\text { people }\end{array}$} & \multicolumn{5}{|c|}{ Share of total public jobs } & \multirow{2}{*}{$\begin{array}{c}\% \\
\text { change, } \\
1980- \\
2000 \\
\end{array}$} \\
\hline & 1965 & 1970 & 1980 & 2000 & 2011 & 1965 & 1970 & 1980 & 2000 & 2011 & \\
\hline Central & 7.8 & 10.0 & 13.6 & 9.9 & 12.4 & $8 \%$ & $8 \%$ & $9 \%$ & $9 \%$ & $8 \%$ & $-27 \%$ \\
\hline Dar es Salaam & 59.9 & 55.4 & 41.0 & 23.5 & 25.9 & $19 \%$ & $18 \%$ & $16 \%$ & $13 \%$ & $25 \%$ & $-43 \%$ \\
\hline Eastern & 9.0 & 11.0 & 14.1 & 12.8 & 12.0 & $9 \%$ & $9 \%$ & $9 \%$ & $9 \%$ & $9 \%$ & $-9 \%$ \\
\hline Lake & 5.7 & 6.9 & 9.0 & 7.2 & 7.4 & $13 \%$ & $13 \%$ & $13 \%$ & $16 \%$ & $16 \%$ & $-20 \%$ \\
\hline Northern & 10.2 & 11.7 & 15.1 & 10.3 & 13.5 & $6 \%$ & $5 \%$ & $6 \%$ & $6 \%$ & $7 \%$ & $-32 \%$ \\
\hline Southern & 6.4 & 8.8 & 12.9 & 11.9 & 7.9 & $8 \%$ & $9 \%$ & $10 \%$ & $11 \%$ & $8 \%$ & $-8 \%$ \\
\hline Southern & & & & & & & & & & & \\
\hline Highlands & 6.3 & 7.1 & 10.3 & 9.8 & 7.2 & $8 \%$ & $7 \%$ & $9 \%$ & $11 \%$ & $6 \%$ & $-5 \%$ \\
\hline Tanga & 11.8 & 16.1 & 16.6 & 9.3 & 7.7 & $15 \%$ & $17 \%$ & $14 \%$ & $8 \%$ & $7 \%$ & $-44 \%$ \\
\hline West Lake & 7.0 & 8.0 & 10.2 & 4.7 & 9.4 & $4 \%$ & $4 \%$ & $4 \%$ & $3 \%$ & $5 \%$ & $-54 \%$ \\
\hline Western & 9.8 & 10.9 & 12.1 & 10.7 & 7.6 & $11 \%$ & $10 \%$ & $10 \%$ & $13 \%$ & $10 \%$ & $-11 \%$ \\
\hline Natl. Average & 10.6 & 12.1 & 13.7 & 10.5 & 10.5 & & & & & & \\
\hline $\begin{array}{l}\text { Natl. Average, } \\
\text { excl. Dar }\end{array}$ & 7.9 & 9.8 & 12.2 & 9.5 & 8.9 & & & & & & \\
\hline$C V$ & 1.23 & 1.00 & 0.60 & 0.45 & 0.52 & & & & & & \\
\hline
\end{tabular}

a. See Appendix S2 for mapping of current regions onto historical provinces, p. 15.

b. Tanzanian data is only available for the general government, and thus excludes the parastatal sector.

Sources: 1965-1980: Tanzania, Survey of Employment and Earnings; Tanzania, HBS 2000/01; Tanzania, HBS 2011/12.

\section{Uganda}

\begin{tabular}{|c|c|c|c|c|c|c|c|c|c|c|c|c|}
\hline \multirow{2}{*}{ Region } & \multicolumn{6}{|c|}{ Public employees per 1,000 people } & \multicolumn{6}{|c|}{ Share of total public jobs } \\
\hline & 1965 & 1970 & 1987 & 1992 & 2002 & 2006 & 1965 & 1970 & 1987 & 1992 & 2002 & 2006 \\
\hline Central & 9.6 & 10.8 & 14.0 & 16.0 & 8.6 & 7.8 & $21 \%$ & $20 \%$ & $21 \%$ & $19 \%$ & $18 \%$ & $19 \%$ \\
\hline Eastern & 10.0 & 11.6 & 15.9 & 21.3 & 9.1 & 11.2 & $24 \%$ & $23 \%$ & $24 \%$ & $27 \%$ & $21 \%$ & $28 \%$ \\
\hline Northern & 8.5 & 10.1 & 11.8 & 16.7 & 12.2 & 8.7 & $16 \%$ & $15 \%$ & $14 \%$ & $17 \%$ & $18 \%$ & $17 \%$ \\
\hline Western & 9.7 & 11.8 & 14.9 & 18.4 & 16.0 & 10.1 & $22 \%$ & $22 \%$ & $25 \%$ & $22 \%$ & $33 \%$ & $26 \%$ \\
\hline Kampala & 51.0 & 80.3 & 53.9 & 58.8 & 21.3 & 16.3 & $16 \%$ & $21 \%$ & $15 \%$ & $14 \%$ & $10 \%$ & $10 \%$ \\
\hline Natl. & & & & & & & & & & & & \\
\hline Average & 10.9 & 13.5 & 16.2 & 20.3 & 11.9 & 9.9 & & & & & & \\
\hline$C V$ & 1.05 & 1.24 & 0.81 & 0.70 & 0.39 & 0.31 & & & & & & \\
\hline
\end{tabular}

Sources: 1965-70: Uganda, Enumeration of Employees; 1987: Uganda, Background to the budget 1989/90, Table 32.; Uganda, IHS 1992/93; Uganda, NHS 2002/03; Uganda, NHS 2005/06. 


\section{Footnote references}

Abernethy, D. 'Bureaucratic growth and economic stagnation in sub-Saharan Africa', in S. Commins ed., Africa's Development Challenges and the World Bank, (Bounder, CO, 1988), pp. 179-214.

Adedeji, A. 'Comparative strategies of economic decolonization in Africa', in General History of Africa, Vol VIII, Africa since 1935, Mazrui, A. (eds) (Paris, 1993), pp. 393-431.

Acemoglu, D. and Robinson, J. A. 'Why is Africa poor?', Economic History of Developing Regions 25, no. 1 (2010), pp. 21-50.

Alesina, A., Baqir, R. and Easterly, W. 'Public goods and ethnic divisions', Quarterly Journal of Economics, 114, no. 4 (1999), pp. 1243-84.

Alesina, A. and Drazen, A. 'Why are stabilizations delayed?' American Economic Review, 81, no.5 (1991), pp.1170-88.

Andrews, M., Pritchett, L. and Woolcock, M. 'Escaping capability traps through problem driven iterative adaptation (PDIA)', World Development, 51, issue C (2013), pp. 234-44.

Arrighi, G. and Saul, J. S. 'Socialism and economic development in tropical Africa', Journal of Modern African Studies, 6, no. 2 (1968), pp. 141-69.

Austin, G. 'The Developmental state and labour-intensive industrialization: 'late development' reconsidered', Economic History of Developing Regions, 25, no. 1 (2010), pp. 51-74.

Bates, R. H., Markets and states in tropical Africa: The political basis of agricultural policies (Berkeley and London, 1981).

Bennell, P. 'The colonial legacy of salary structures in anglophone Africa', Journal of Modern African Studies, 20, no. 01 (1982), pp. 127-54.

Berman, B. J. 'Ethnicity, patronage and the African state: the politics of uncivil nationalism', African Affairs, 97 (1998), pp. 305-41.

Bigsten, A., Education and income determination in Kenya (Hampshire and Brookfield, 1984).

Income distribution and growth in a dual economy: Kenya, 1914-1976 (Gothenburg, Memorandum edn, 1987).

Bigsten, A. and Moene, K. 'Growth and rent dissipation: the case of Kenya', Journal of African Economies, 5, no.2 (1996), pp.177-98.

Binder, A. J., Zaman, A., Mauro, P. and Romeu, R. 'A Modern history of fiscal prudence and profligacy', WP/13/5 (International Monetary Fund, Washington D.C., 2013).

Birdsall, N., William, J. and Deese, B. 'Delivering on debt: from IMF gold to a new aid architecture' (Center for Global Development, Washington D.C., 2002).

Clapham, C. Third world politics: an introduction (Maddison, Wisconsin, 1985).

Clapham, C. 'Governmentality and economic policy in sub-Saharan Africa,' Third World Quarterly, 17 no.4 (1996), pp.809-24.

Chabal, P., and Daloz, J. P. Africa Works: Disorder as political instrument (James Currey, Oxford, 1999).

Chenery, H. B. and Strout, A. M. 'Foreign assistance and economic development', American Economic Review, 56, no. 4, Part 1 (1966), pp. 679-733.

Chew, D. 'Internal adjustments to falling civil service salaries: insights from Uganda,' World Development, 18, no.7 (1990), pp.1003-14.

Cogneau, D., Dupraz, Y. and Mesple-Somps, S. 'African states and development in historical perspective: colonial public finances in British and French West Africa' (Paris School of Economics Working Paper, Paris, 2016).

Cohen, J. M. 'Importance of public dervice reform: the case of Kenya', Journal of Modern African Studies, 31, no. 3 (1993), pp. 449-76.

Collier, P. and Lal, D., Labour and poverty in Kenya, 1900-1980 (Oxford, 1986).

Collier, P. and Gunning, J. W. 'Why has Africa grown so slowly', Journal of Economic Perspectives, 13, no.3 (1999), pp.3-22.

Cooper, F., Decolonization and African society: the labor question in French and British Africa (Cambridge, 1996). Africa since 1940: the past of the present (Cambridge, 2002).

Currie, J., and van L. Maas, J. 'Uganda's Secondary School Graduates: Postponement of Labour Market Entry' Manpower and Unemployment Research in Africa, 7, no.1 (1974), pp. 14-31.

Easterly, W. and Levine, R. 'Africa's growth tragedy: policies and ethnic divisions', Quarterly Journal of Economics, 12, no. 4 (1997), pp. 1203-50.

Englebert, P. 'Pre-colonial institutions, post-colonial states, and economic development in tropical Africa', Political Research Quarterly, 53, no. 1 (2000), pp. 7-36.

Francois, P., Rainer, I. and Trebbi, F. 'How is power shared in Africa?' Econometrica, 83, no.2 (2015), pp. 465503. 
Frankema, E. 'Colonial taxation and government spending in British Africa, 1880-1940: maximizing revenue or minimizing effort?', Explorations in Economic History, 48, no. 1 (2011), pp. 136-49.

'The origins of formal education in sub-Saharan Africa: was British rule more benign ?', European Review of Economic History, 16, no. 4 (2012), pp. 335-55.

Freund, B., The African worker (Cambridge, 1988).

Gardner, L. A., Taxing colonial Africa: The political economy of British Imperialism (Oxford, 2012).

Gelb, A., Knight, J. B. and Sabot, R. H. 'Public sector employment, rent seeking and economic growth', Economic Journal, 101, no.408 (1991), pp.1186-99.

Githinji, M. W. Ten millionaires and ten million beggars (Aldershot, 2000).

Goldsmith, A. A. 'Africa's overgrown state reconsidered: bureaucracy and economic growth', World Politics 51, no. 4 (1999), pp. 520-46.

Goldsmith, A. A. 'Sizing up the African state', Journal of Modern African Studies, 38, no. 1 (2000), pp. 1-20.

Hannah, L. 'A failed experiment: The state ownership of industry', in R. Floud and P. Johnson eds., The Cambridge economic history of modern Britain, Vol. 3, Structural change and growth, 1939-2000, (Cambridge, 2004), pp. 84-111.

Hughes, R. (1987). 'Revisiting the fortunate few: University graduates in the Kenyan labor market', Comparative Education Review, 31, no. 4, (1987), pp. 583-601.

Jamal, V. and Weeks, J. Africa misunderstood, or whatever happened to the rural-urban gap? (ILO studies, Basingstoke, 1993).

Kenya Institute for Public Policy Research and Analysis. 'A comparative study on public-private sector wage differentials in Kenya' (KIPPRA Policy Paper, Nairobi, 2013).

Kinyanjui, K. 'Education, training and employment of secondary school leavers in Kenya', in D. Court and D. Ghai eds., Education, society and development: new perspectives from Kenya (Nairobi, 1974), pp.

Langseth, P. 'Civil service reform in Uganda: lessons learned', Public Administration and Development, 15, no. 1 (1995), pp. 365-90.

Leinert, I. and Modi, J. 'A decade of civil service reform in Sub-Saharan Africa' (International Monetary Fund, Washington D.C., 1997).

Lindauer, D. and Nunberg, B. Rehabilitating government: pay and employment reform in Africa (World Bank, Washington D.C., 1994).

Lindauer, D. L. and Sabot, R. H. 'The public/private wage differential in a poor urban economy', Journal of Development Economics, 12, no. 1 (1983), pp. 137-52.

Lindemann, S. 'Exclusionary elite bargains and the civil war onset: the case of Uganda' (Crisis States Research Centre, London, 2010).

Lindert, P. H., Growing public: social spending and economic growth since the eighteenth century (Cambridge, 2004).

Lorete, S. M. 'The Kenya civil service reform programme: analysis of the design and implementation of retrenchment policy' (unpub. masters thesis, Erasmus University, 2002).

Lukumai, E. C. 'The implementation of civil service reforms in Tanzania, 1991-2000' (unpub. masters thesis, University of Bergen, 2006)

Mamdani, M., Politics and class formation in Uganda (New York and London, 1976).

- Define and rule: native as political identity (Cambridge, MA and London, 2012).

Mkandawire, T. 'Neopatrimonialism and the political economy of economic performance in Africa: critical reflections' World Politics, 67, no. 3 (2015), pp. 563-612.

Mukui, J. T. 'The Politics and economics of the 1979 tripartite agreement in Kenya: a note', African Affairs, 82, no. 329 (1983), pp. 559-63.

Nyerere, J. K., 'President's inaugural address', in J. Nyerere eds, Freedom and Unity/Uhuru na Umoja: A Selection from Writings and Speeches 1952-65 (London, 1966).

Okurut, F. N. and Ssewanyana, S. 'Determinants of wage earnings in Uganda', IUP Journal of Agricultural

Economics, No.2 (2007), pp. 60-79.

Pradhan, S., Evaluating public spending: a framework for public expenditure reviews, (World Bank, Washington D.C., 1996)

Robinson, J. A. and Verdier, T. 'The political economy of clientelism', Scandinavian Journal of Economics, 115 , no. 2 (2013), pp. 260--291.

Rodrik, D. 'What drives public employment in developing countries ?', Review of Development Economics, 4 , no. 3 (2000), pp. 229--243.

Rose, R., Public employment in western nations (Cambridge, 1985).

Sabot, R. H. and Knight, J. B., Education, productivity, and inequality: the East African natural experiment (Oxford, 1990).

Schiavo-Campo, S., de Tommaso, G. and Mukherjee, A. 'Government employment and pay: a global and regional perspective', (World Bank policy research working papers, Washington D.C., 1997). 
Sendyona, M. G. 'Public service restructuring and pay reform', in F. Kuteesa, E. Tumusiime-Mutebile, A. Whitworth and T. Williamson eds., Uganda's economic reforms: insider accounts, (Oxford, 2009), pp. 89-102.

Shivji, I. G., Class struggles in Tanzania (London, 1976).

Simson, R. '(Under)privileged bureaucrats?: the changing fortunes of public servants in Kenya, Tanzania and Uganda, 1960-2010' (unpub. Ph.D thesis, London School of Economics, 2017).

, 'Ethnic (in)equality in the public services of Kenya and Uganda,' African Affairs, forthcoming (2009).

Tanzi, V. and Schuknecht, L., Public spending in the 20th century: a global perspective (Cambridge and New York, 2000).

Teskey, G. and Hooper, R. 'Tanzania civil service reform programme: a case study' Paper given to the joint DAC Informal Network/ACBF workshop on operational approaches to institutional and capacity development (Harare, 1999).

Todaro, M. P. 'A model of labor migration and urban unemployment in less developed countries', American Economic Review, 59, no. 1 (1969), pp. 138-48.

Valentine, T. 'Government wage policy, wage and employment trends, and economic instability in Tanzania since independence' (Economic Research Bureau Paper, Dar es Salaam, 1981).

Webber, C. and Wildavsky, A., A history of taxation and expenditure in the western world (New York, 1986).

Weeks, J. F. 'Wage policy and the colonial legacy - a comparative study', Journal of Modern African Studies, 9 , no. 3 (1971), pp. 361-87.

World Bank. 'Cost-benefit analysis in education: a case study on Kenya' (World Bank, Washington D.C., 1969)

\section{Official publications and data sources}

Ani, M. O. 'Report of the Uganda Civil Service Salaries Commission', (Entebbe, 1963).

Afrobarometer Data, Kenya, Tanzania and Uganda, Rounds 1, 2 and 3, 1999-2006 (Available at http://www.afrobarometer.org)

Colony and protectorate of Kenya. '1961/62 Estimates of Expenditure of the Colony and Protectorate of Kenya' (Nairobi, 1961).

Government of Kenya. 'Sessional Paper No. 10 of 1967, Proposals by the Government of Kenya for the Implementation of the Recommendations Contained in the Report of the Public Service Salaries Review Commission' (Nairobi, 1967).

-. 'Sessional Paper No.10 of 1980 on the Acceptance and Implementation of the Recommendations of the Civil Service Review Committee, 1979/80', (Nairobi, 1980).

'Budget Speech 1984/85' (Nairobi, 1984).

Government of Tanganyika. 'Development Plan for Tanganyika, 1961/62 - 1963/64' (Dar es Salaam, 1961).

International Monetary Fund. 'Uganda: Recent Economic Developments' (Washington D.C., 1983).

Kenya Bureau of Statistics. 'Employment and earnings in the modern sector', various years (Nairobi 1972-85) ' 'Statistical Abstract', various years (1976-2011).

Kenya Civil Service Reform Committee, 'Report of the civil service salaries review committee 1985', (Government printer, Nairobi, 1985).

Minnesota Population Center, 'Kenya 2009 Population and Housing Census', IPUMS International: Version 6.3 [Dataset] (Minneapolis, University of Minnesota, 2015).

Republic of Kenya. '2011/12 Estimates of Recurrent Expenditure of the Government of Kenya' (Nairobi, 2011).

Tanzania National Bureau of Statistics. 'Survey of Employment and Earnings 1973-1974' (Dar es Salaam, 1974).

'Survey of Employment and Earnings', various years (Dar es Salaam, 1965-1980).

'Household Budget Survey 2000/01' [Dataset].

'Household Budget Survey 2011/12' [Dataset].

Uganda. 'Sessional Paper No.2 of 1962: Proposals for the Implementation of the Main Recommendations of the Report of the World Bank Economic Survey Mission - "the Economic Development of Uganda." (Entebbe, 1962).

'Background to the Budget 1963/64' (Entebbe, 1963).

'Background to the Budget 1966/67' (Entebbe, 1967).

'Background to the Budget 1989/90' (Entebbe, 1989).

'Enumeration of Employees', various years (1965-1980).

Uganda Bureau of Statistics. 'Integrated Household Survey 1992/93' [Dataset].

'National Household Survey 2002/03' [Dataset].

'National Household Survey 2005/06' [Dataset]. 
World Bank. 'Tanzania: Basic Economic Report, Annex 1 - Domestic Finance and Resource Use' (Washington D.C., 1977).

'Accelerated Development in Sub-Saharan Africa: An Agenda for Action' (Washington D.C., 1981).

'Tanzania: Public Expenditure Review' (Washington D.C., 1989).

' 'Uganda: Growing out of Poverty' (Washington D.C., 1993).

Worldwide Governance Indicators (Available at: www.govindicators.org)

\section{Supporting Information}

Appendix S1: Public expenditure and employment in Kenya, Tanzania and Uganda: data Appendix S2: Construction of data series 